\title{
'The Golden Chain of Pious Rabbis' The origin and development of Finnish Jewish Orthodoxy
}

\author{
Simo Muir and Riikka Tuori

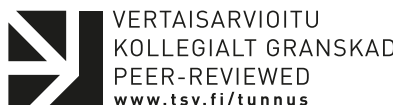

DOI: https://doi.org/10.30752/nj.77253

Aвstract - This article provides the first historiographical analysis of the origins of Jewish Orthodoxy in Helsinki and describes the development of the rabbinate from the establishment of the congregation in the late I 85 os up to the early I 980 s. The origins of the Finnish Jewish community lies in the nineteenth-century Russian army. The majority of Jewish soldiers in Helsinki originated from the realm of Lithuanian Jewish (Litvak) culture, that is, mainly non-Hasidic Jewish Orthodoxy that emerged in the late eighteenth century. Initially, the Finnish Jewish religious establishment continued this Orthodox-Litvak tradition. After the independence of Finland, the Helsinki congregation hired academic, Modern Orthodox rabbis educated in Western Europe. Following the devastation of the Shoah and the Second World War, the recruitment of rabbis faced new challenges. Overall, the rabbi recruitments were in congruence with the social and cultural development of the Helsinki community, yet respected its Orthodox roots.

\section{Introduction ${ }^{1}$}

The liturgical customs of the Jewish Community of Helsinki were codified in 200I, when the long-serving rabbi Moshe Edelmann compiled an extensive manual entitled The Traditional Order of Synagogue Service in the Jewish Community of Helsinki. In the preface, Edelmann (200I) notes that this tradition, Minhag Polin, ${ }^{2}$ has been passed down

1 We are grateful to the following individuals who have assisted us in gathering information or offered valuable comments on the contents of the article: Meliza Amity, Professor Wout van Bekkum, Mercédesz Czimbalmos MA, Dr Laura Ekholm, Professor Galit Hasan-Rokem, Professor Sacha Stern, Dor Treistman, Professor Bart Wallet and Professor Mordechai Zalkin. All the remaining mistakes in the article are ours.

2 Minhag Polin represents the eastern version of the Ashkenazi liturgical rite (Lowen- from generation to generation from the Cantonists, ${ }^{3}$ the former Jewish soldiers who established the community. ${ }^{4}$

stein I997: 63, 74). According to Edelmann (200I), Helsinki has always held on to the traditions of the forefathers (Heb. minhag avotenu be-yadenu).

3 Jewish soldiers from the time of Nicholas I were generally referred to as 'Nicholas's soldiers', and among them only those who had attended a Cantonist school were called Cantonists. In Finland, however, the term is often applied to all Jewish soldiers who served in the tsar's army (Muir 2004: 20).

4 There are many alternative spellings for Polish, Lithuanian, and Russian towns, reflecting the geopolitics of the area. In this article, we use those place names that were mostly used at the time of the life of the individual, and, when needed, show in brackets their modern names. The transliteration of Yiddish follows the general guidelines of YIVO standard spelling, and Hebrew the SBL Handbook of Style. 
Who were the rabbis employed by the Cantonists that ingrained Minhag Polin in the Jewish Community of Helsinki? What kind of Orthodoxy did they represent and how did the rabbinate develop over time? How have local sources described their backgrounds and what did they do after leaving Finland? These are the questions we seek to answer in this article. We aim to give the first overview and analysis of the origin of rabbis and the development of Finnish Jewish Orthodoxy; our approach is historiographical and is based on existing literature, rather than historical documents. Our focus is on the Jewish Community of Helsinki, which was and still is the biggest Jewish congregation in Finland. Jewish soldiers had served in Helsinki since 1827 , when the law enabling Jewish recruitment was passed, but the actual congregation seems to have been founded in I 858 . In this year, the former Jewish soldiers, many of whom had served twenty-five years in the tsarist army, were allowed to settle in the towns where they had served. 5

There are few local sources on the rabbis' lives during their time in Finland. None of the rabbis died in Finland, and it seems that many of them took their personal archives with them when they left the country (Edelmann 2006: 24). One of the few early sources about the religious and cultural life of the Jewish community during the Russian period and beginning of Finnish independence, gained in 1917, is the unpublished manuscript, 'Commemorative Chronicle', written in 1956 by the Helsinki-born merchant Jac Weinstein (1883-1976) in honour

5 Before 1809 , Swedish law forbade Jews from living in Finland, and after Finland's annexation to Russia in I 809, the old Swedish constitution remained in force until Finland became independent in I9I 7. On Jewish soldiers in the Russian army, see, e.g., Petrovsky-Shtern 2008. of the fifty-year jubilee of the Helsinki synagogue. Weinstein provides the first description of the development of religious life with its institutions and a list of rabbis up to the mid-I95os. He had studied law at the Imperial Alexander University in Helsinki, and worked for several years as the secretary of the Jewish congregation and researched the history of the community (Muir 2010). Unfortunately, his I 956 chronicle does not provide much information about his sources. There are big gaps in the Finnish Jewish archives at the National Archives of Finland relating to the late nineteenth century, and it is likely that besides oral history and his own memories, Weinstein had to hand documentation that no longer exists. Weinstein does not supply any information about the backgrounds of the rabbis before their arrival in Helsinki.

Weinstein's manuscript has served as a source for later studies and works concerning the Helsinki community. The political historian Taimi Torvinen's Kadimah. Suomen juutalaisten historia ('The History of Jews in Finland', I 989), which still is the most comprehensive work on the history of the community, relies mostly on Weinstein when discussing the evolution of the Finnish Jewish religious establishment. Torvinen's work, though, focuses on the historical development of the community, civil rights and Jewish refugees during the Second World War, and in general pays little attention to religious life and customs.

Moshe Edelmann, the previous chief rabbi of Finland, was the first to study Jewish religious life in Helsinki. His work has resulted in many publications, such as The Traditional Order of Synagogue Service (mentioned above) and several collections of rabbinical responsa literature, sermons and lectures, many of them concerning Finland. Besides Weinstein's manuscript, Edelmann 
had access to some previously unused archival material. In 2006, Edelmann published articles about three rabbis in Helsinki in the Jewish journal Hakebila, and revised versions of these articles were later published in the Kansallisbiografia ('Finnish National Biography').

Besides this literature on the rabbis in Helsinki, a few other sources in Yiddish, Hebrew, Polish and English are available. Some works and several entries in encyclopedias have been written about some of the more prominent rabbis, for instance about Naftali Amsterdam, who was a student of Rabbi Israel Salanter, the father of the Musar movement, and Simon Federbusch, who was one of the founders and leaders of the religious-Zionist Mizrachi movement in Galicia, Poland. One of the rabbis, Mika Weiss, wrote an autobiography, where he also reflected on his time in Finland. In addition, Meliza Amity's genealogical website offers invaluable details about the life of the Finnish Jewish community, including the rabbis.

Sometimes our depictions of the rabbis remain somewhat limited owing to a lack of details in our literature and sources. We discuss the rabbis' families, especially the wives, who were sometimes the main providers for their families. ${ }^{6} \mathrm{We}$ also examine how

6 Rabbis' wives (known in Yiddish as the rebetsin) have always played an important role in Jewish societies. However, depictions of these wives or Jewish women in general are brief in the literature dealing with the rabbis, and historical works written by the women themselves are rare. For a rare depiction of the changing role of Jewish women and family in nineteenth-century Russia on the threshold of modernity, see the memoirs of Pauline Wengeroff (1833-1916) (Wengeroff I908). In I 866-70, Wengeroff lived in Helsinki with her family among the Cantonist soldiers in Sveaborg as her husband worked as a supplier in the Russian army. the rabbis interacted with local religious life and encountered modernisation in the small Jewish community, confronting, for example, the pressing problems of mixed marriages and their consequences, including conversion procedures.

The article covers a long period of time, during which major changes were taking place in East European Jewish society. According to the historian Marc B. Shapiro:

By the last two decades of the nineteenth century, although most east European Jews were still traditional, the guardians of tradition were confronted with an entirely new challenge, and never before had it been so difficult to retain the allegiance of the young $[. .$.$] and important elements of$ traditional society $[\ldots]$ began to be questioned. (Shapiro I999: I)

Even though it was on the periphery, away from the Jewish centres, this change was taking place in Helsinki too: as we show, at the beginning of the twentieth century there was a shift in the rabbinate from traditional East European Orthodoxy towards modern Western Orthodoxy. After the Shoah, finding suitable candidates for the rabbinate in Helsinki from Europe became extremely challenging, and the Jewish community turned its eyes towards Israel.

We show that the case of Helsinki - and Finland - is unique: because Finnish Jewry survived the Shoah more or less intact, its Orthodoxy represents a direct continuum from the establishment of the community up to today. We also demonstrate how the Shoah indirectly influenced the community and the recruitments of the rabbis in Helsinki. We can thus analyse how the rabbinate continued and developed after the Shoah in a community that originally represented East European Orthodoxy. In what 
follows, we analyse the historiography of rabbis in Helsinki, from the first known rabbi in I 867 until the last rabbi trained in Europe left his office in 1982 . We have divided this time into three periods: I) rabbis during the Grand Duchy of Finland (the 'Spiritual'), 2) rabbis after the independence of Finland (the 'Academics'), and 3) rabbis during the Cold War (the 'Shoah survivors') (see the chart 'Rabbis in Helsinki I867-r982' at the end of this article).

\section{The Spiritual:}

\section{rabbis during the Grand Duchy of Finland}

In his 'Commemorative Chronicle', Weinstein describes the early state and development of religious life among the Cantonist soldiers in Helsinki. He indicates that there was already a prayer house on the fortress island of Sveaborg (Suomenlinna), which guarded Helsinki, in the middle of the 1830 os. In 1858 , when the former Cantonists were granted permission to settle in the towns where they had served, a specific location was designated for general synagogue services in mainland Helsinki that was also visited by new Jewish recruits (Halén 2004: 27). The first persons nominated to the post of rabbi were themselves former soldiers, who seem to have lacked proper qualifications to act as rabbis. ${ }^{7}$ In 1870 , what Weinstein calls 'the first actual synagogue' in Helsinki was

7 According to Harry Halén (2004: 27-9), at the request of the community the Russian officials nominated rank-and-filer Zelig Voislovski as a rabbi on I 9 February I 858 . Ten years later, 3 I July I 868 , the community applied for permission to invite a qualified person to run the services. Until August that year, the war invalid Israel Morduch (Mordock) had been in charge. In September 1 868, Rabbi Hirsch Rain arrived from Vyborg (Viipuri) to lead the synagogue. established in Langén's villa on Siltasaari Island, and as a consequence the synagogue in Sveaborg was closed down. The rent for the synagogue was paid by the Russian officials as part of the privileges of the former Cantonists (Weinstein r 956, I 964.)

During Russian rule, Jewish communities had to have a rabbi officially approved by the state. These rabbis were known as 'crown rabbis' (Russian kazionnyi ravvin), who maintained the Jewish population register and represented the community to the authorities, enforcing loyalty to the Empire and its laws. Many were trained in Russian-language rabbinical seminars with an emphasis on secular education, and hence lacked authority in religious matters (Kaplan Appel 20ro; Shapiro I999: I9). According to Weinstein ( 956 ), the only crown rabbi in Finland was Jakob Jakobowitsch ( I 849-1922), ${ }^{8}$ who held the position from the mid-I870s to the early I 900 s.

Edelmann (20Iob) claims that the crown rabbis' knowledge of Jewish law was often poor and that they were 'morally dubious from a traditional religious point of view'. Congregations preferred their own employees, the traditional rabbis selected by the congregants, known in Russian as dukbovnyi ravvin ('spiritual rabbi'). Weinstein lists four such rabbis serving the Jewish Community of Helsinki during the Russian rule: Naftali Amsterdam, Avrohom Schain, Aba WernerHoma and Schmuel Noson Bukantz. ${ }^{9}$ As we show below, all of them originated from

8 According to Meliza Amity's genealogical website, Jakobowitsch was born in Lututów, Łódź province. Besides acting as a 'Jewish priest', he was also registered as a soldier and a tailor (see Amity I).

9 We do not know whether this is a complete list of rabbis who served during this time. Weinstein himself refers to lack of documentation when listing religious workers in general. 
Lithuania, and three of them were trained in the famous Lithuanian yeshivot. The available literature does not provide information on how or by whom they were recruited. However, research on the origins of Jewish soldiers in Helsinki shows that a majority of them also originated from Lithuania, north-east Poland and Belorussia, in other words from the realm of Lithuanian Jewish, or Litvak, culture (Harviainen I998: 297; Muir 2004: 2 I-6). A study on the varieties of Yiddish spoken in Helsinki also shows the predominance of the Lithuanian dialect, and certain cultural traits of the community are Litvak, for instance, not seasoning the gefilte fish with sugar as was customary in Poland (Muir 2004: 29, I39).

Litvak culture encompasses much more than ethnicity or linguistic and cultural characteristics: it refers to non-Hasidic Jewish Orthodoxy. From the late eighteenth century onwards, East European Judaism had been divided into two camps: Hasidism with its strong dynasties of charismatic leaders, Rebbes, and teachings emphasizing social involvement and devotedness to God, and Mitnaggedim, the mainly Lithuanian opponents of Hasidism. While the Hasidic movement had swiftly gained ground across Poland, Ukraine and Belorussia, the major cluster that held sway against Hasidism emerged in Lithuania: Elijah ben Shlomo, the Gaon of Vilna, opposed the changes brought to Jewish leadership through the charismatic Rebbes and the 'anti-intellectual' stance of Hasidic innovators. ${ }^{10}$ As we shall see below,

10 These relations were, obviously, more nuanced from early on, and during the nineteenth century the boundaries separating Hasidim and Mitnaggedim become more blurred (Wodziński 20 I 8: 3I-2). Nevertheless, both groups also developed and maintained their own educational systems. the Finnish Jewish religious establishment has its roots in this Orthodox-Litvak tradition: the earliest rabbis in Helsinki had studied in Litvak yeshivot and followed the teachings of prominent Litvak teachers.

According to Jac Weinstein (1956) and Santeri Jacobsson (195 r: 97-100), many of the Cantonists had become estranged from Judaism during their twenty-five years of service but tried their best to fulfil their religious duties. One may ask why they opted to continue with Orthodox Judaism: probably they lacked other options, as this was the only form of Judaism they had known in their youth. Arriving from the lower strata of society in the shtetls of the Pale of Settlement, they were not familiar, for example, with the Reform movement that was only starting to emerge in the major cities of the Russian Empire. ${ }^{11}$ Most of the Jewish soldiers were recruited from the area surrounding the Vilna province, where Hasidism had not gained a foothold.

\section{Naftali Amsterdam (1832-1916), rabbi 1867-75}

The first known spiritual rabbi in Helsinki, Naftali Dov Amsterdam, was born in Salantai, Lithuania, in I 832. According to Edelmann (20IOa), not much is known about his birth family, but he used the patronym Shlomo, or Shlomo Zalman. At a young age Amsterdam became one of the most prominent students of Israel Salanter (1810-83), the founder of the Musar movement, a Lithuanian Orthodox reaction against the reforming forces of the Maskilim on the one hand, and the success

11 At this point, religious reform was mostly successful in those (mostly West European) countries where Jews could aspire to equality; in Russia, this was in general more difficult (Meyer 2010). 


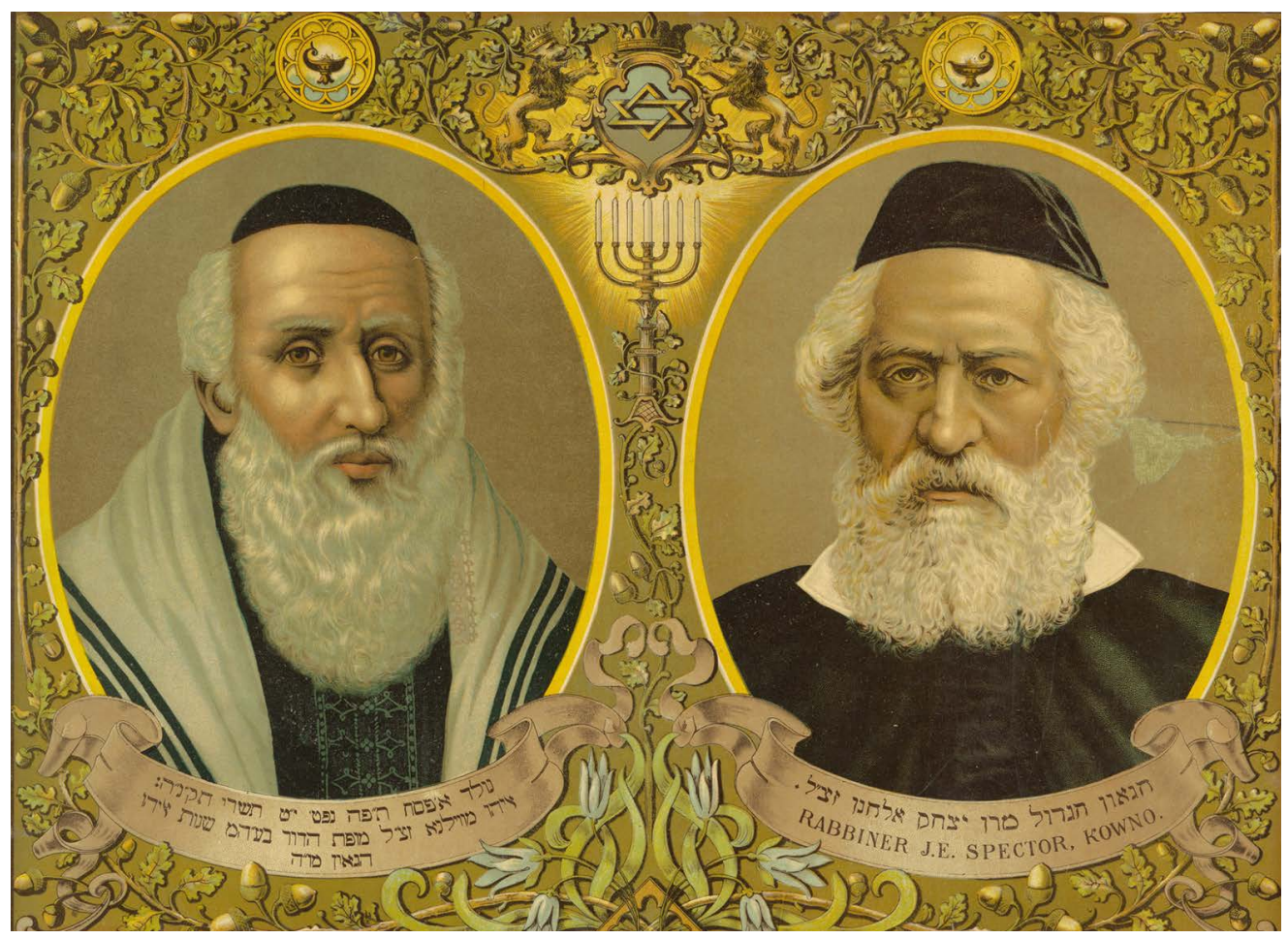

A picture of two influential figures of Lithuanian (Litvak) Judaism, the Gaon of Vilna and Yitshak Elhanan Spektor of Kovno, was found in the cellar of the Helsinki synagogue in 2005. Most of the Jewish soldiers arriving in Finland in the nineteenth century originated from the Litvak communities and recruited the first rabbis from the area. Finnish Jewish Archives, National Archives of Finland.

of Hasidism on the other. ${ }^{12}$ As discussed by Shaul Stampfer (20I2) and Immanuel Etkes (1993), the proponents of the movement launched an educational reform in the yeshivot they established in various locations in Lithuania, most notably in Slobodka in the suburbs of Kovno. Salanter himself had been heavily influenced by the ideas of the earlier Litvak intellectuals Hayyim of Volozhin and the Gaon of Vilna.

Amsterdam studied in seminaries founded by Salanter in Kovno and in Vilna, and throughout his life he remained in close

12 The movement emphasized ethical behaviour based on the sound learning of halakhic works as well as ethical treatises.

For more on the Musar movement and Salanter's ideological development, see Etkes (1993). contact with his teacher (Mirsky 20 Io). After marrying, Amsterdam opened a bakery in Kovno, but Salanter urged him to continue his Torah studies, and his wife Rivka (née Ittelson, d. I902) operated the bakery. ${ }^{13} \mathrm{At}$ this point, Amsterdam's involvement with the Musar movement and Salanter impeded his career path: when Salanter tried to get his student employed as a rabbi in Moscow, local Hasidim acted against his appointment. The case reflects the strained relations of Hasidim

13 In nineteenth-century Poland and Lithuania, a young woman's ability to support the family and conduct business was a valued skill in the marriage market: in a family of a Talmudic scholar, the wife was often the only breadwinner (Etkes I 989 : I66-7). 
and Mitnaggedim in mid-nineteenth-century Russia (Edelmann 20 10a).

In 1867 , Amsterdam accepted a rabbinical position in Helsinki. Edelmann correctly speculates that his decision was based on financial reasons: in letters to his friend Yitshak Blazer, the chief rabbi of St Petersburg, Amsterdam describes the difficulties of combining Torah study and supporting the family. Salanter, however, had opposed Amsterdam's decision to work in the bakery and recommended that he should rather find a rabbinical post, which entailed separation from the family. Following Salanter's advice, Amsterdam had been actively looking for a position until finally landing in Helsinki (Etkes I 989: 167-8, I 74).

Amsterdam remained in office in Helsinki for six years, but continued to look for better positions. In I87 I, he was briefly appointed as a rabbi in one of the centres of the Musar movement, Novogrudok (Navahrudak) in the Grodno region, returning, however, to Helsinki a mere year later. At the time he also exchanged letters with Yitshak Elhanan Spektor, the rabbi of Kovno, a Talmudic scholar and yet another friend of Salanter (Edelmann 2oroa). ${ }^{14}$ During Amsterdam's assignment in Helsinki, the legal status of the Jews (the 'Jewish question') was intensely debated in the Finnish Senate from I 872 onwards (Jacobsson I 95 I: I 52 , I 55 ). Throughout his years in Helsinki, Amsterdam's wife ran the bakery in Kovno, and he did not bring her or their children to Helsinki. ${ }^{15}$

14 In many of his surviving letters, Amsterdam wrote about the life and ideas of Salanter; for excerpts, see Etkes (I 993).

15 Rivka did visit Helsinki in I 872. Later Amsterdam tried to find business opportunities for her in Helsinki but failed (Etkes I989: r68).
In I 875, Amsterdam finally returned home. Two years later, he became the deputy of Yitshak Blazer in St Petersburg, and from 1880 onwards he worked as a rabbi in the Kovno district. After a few more years of service, he finally dedicated himself to Torah study with the support of his wife's bakery (Edelmann 20roa). Amsterdam remained close to the yeshivot of the Musar movement in Kovno and Slobodka and published articles on education in the Orthodox newspaper Ha-Levanon ${ }^{16}$ (Lipetz et al. I967: 29).

In I 906, the widowed Amsterdam moved to Jerusalem and opened a school focusing on Musar teachings, and his charitable work in Jerusalem was praised in a letter sent to Amsterdam by Avraham Yitshak Kook, later the first Ashkenazi chief rabbi of Palestine. Amsterdam passed away in I 9 I 6 in Jerusalem (Edelmann 2oroa).

\section{Avrohom Yitzchak Schain (1841/2 - after 1907), rabbi 1876-81}

Avrohom Yitzchak Schain (Schunman, later Shyne) was born in I84 I or in I 842 in Novo Aleksandrovsk (Zarasai), in north-eastern Lithuania. There is no information about his rabbinical education: he was employed as a rabbi in Helsinki from 1876 to $\mathrm{I} 88 \mathrm{I}$. He had three children with his wife Sara (b. I 845), and the family lived on Laivurinkatu 23 in southern Helsinki (Amity 2). According to Weinstein (1964), in I879 he founded Hevra Biqqur Holim, the first Jewish society in Helsinki for the care of the infirm congregants. In the early I88os Schain left Helsinki and moved to the United Kingdom to work as the rabbi of the Jewish community in Gorbals (1885-1907) in Glasgow,

16 Ha-Levanon (Jerusalem, I 863-86) mainly published news about the Old Yishuv but later on expressed sympathy to the early Russian Zionist movement Hovevei Zion. 
Scotland. At this point his surname was anglicised as Shyne (Alderman I 992: I 44).

In Gorbals, Schain became, in the true sense of the word, the 'spiritual' rabbi of the community. As a Yiddish-speaker Schain was never officially nominated to the position of chief rabbi. However, owing to his popularity among the older, Yiddish-speaking immigrants he became an unofficial 'chief rabbi' responsible for kashrut supervision: his congregants volunteered to collect money for his weekly salary. In I 898, Schain was one of the founders of the first Zionist organisation in Glasgow. After the murderous pogrom in Kishinev in 1903 he collected funds for the victims. After his wife's death in I 907, Schain emigrated to Palestine (Collins I990: 53, 88-9, I I 7-I9). 17

\section{Abraham Werner-Homa (1836-1912), rabbi 1881-91}

Most of the information about Abraham (Aba) Werner-Homa ${ }^{18}$ is derived from one source: the history of the Machzike Hadath community in London, written by Homa's grandson, Bernhard Homa, in 1953. Abraham Homa was born in 1836 in Telšiai, in north-eastern Lithuania, to the family of Ya'akov Hayyim and Faiga. In I854, he married Sima Gittel Lipschitz (1837-1 906), and the couple eventually had eleven children. Homa received his smikhah (rabbinical ordination) in 1857 in Žagare and was first employed as a rabbi in Vegeriai and in 1858 back in Telšiai. In I 865 , he was appointed as the $a v-b e t-d i n^{19}$ of Telšiai and received a

17 See also 'Rabbi Shyne: Scottish Jewish Archives Centre'.

18 After arriving in the United Kingdom, Homa changed his name to Werner, following his son who had moved there earlier (Homa I 953: I7).

19 A judge of a rabbinical court; in the Russia second smikhah from Josef Raisin, the previous av-bet-din of the town (Homa r 953: I8). Like Naftali Amsterdam, Homa was connected to the Litvak elite members of the Musar movement: in I 880, Homa exchanged letters with Salanter, who affectionately addresses him as Reb Abtchik. His grandson describes him as a devoted Mitnagged, who followed the teachings of the Vilna Gaon, sharing his negative view of Hasidism and penchant for secular sciences (ibid. 19, 22).

Homa's later years in Telšiai were marred by a conflict between him and some of the congregants, and in the early I 880 the community neglected to pay his wages. During one of Homa's trips to Kovno, his opponents hired another rabbi in his stead. ${ }^{20} \mathrm{In}$ the aftermath, Homa was forced to leave Telšiai and accepted an offer for a rabbinical position in Helsinki (Zalkin 2017: 222-3). Bernhard Homa (I953: I8) succinctly notes that in Tels my grandfather received a call from Helsingfors to become Chief Rabbi ${ }^{21}$ of Finland' and that he moved to Finland in the early I 88 os. $^{22}$

of the time, typically a synonym for a rabbi of a larger district.

20 This rabbi was the former student of Israel Salanter, Eliezer Gordon, who in I 883 became the head of the Telšiai (Telz) Yeshivab; on the early years of this influential Yeshivah, see Stampfer (201 2: 286-336).

21 According to Meliza Amity's genealogical website, Homa arrived in Finland in I 88 I and was appointed as the 'chief rabbi' (of Helsinki?) in I 885 . However, the position of chief rabbi of Finland is used for the first time only in the I93os when Simon Federbusch arrived in Finland.

22 There is some discrepancy in the chronology: according to Weinstein, Homa began his service as a rabbi in Helsinki in 1884 , and according to Amity, in I 885. The year $\mathrm{I} 880 / \mathrm{I}$ is derived from Homa's grandson's memoirs, although this may refer only to his move to Helsinki. 


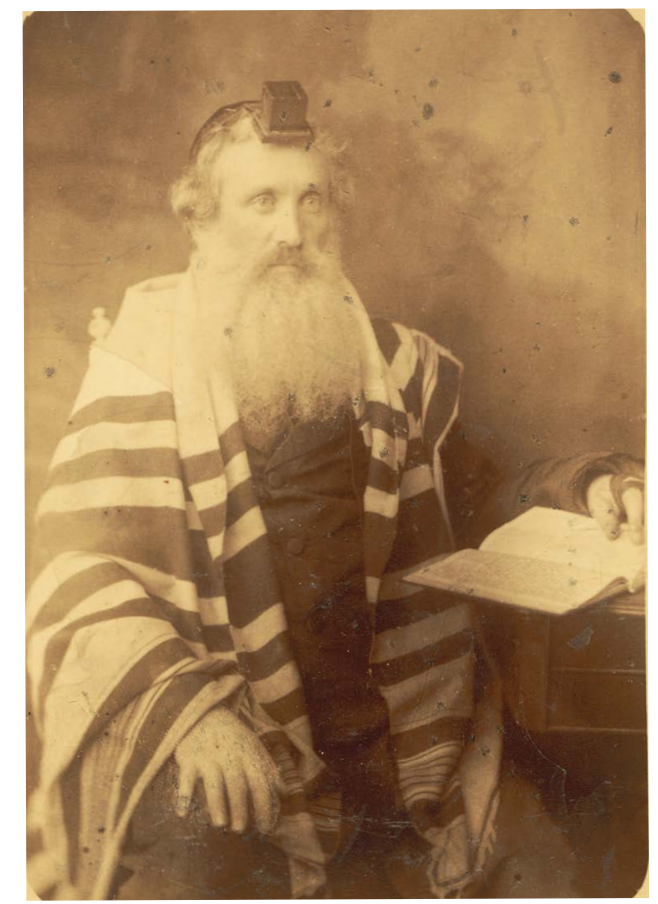

A picture of the third spiritual rabbi in Helsinki, Abraham Werner-Homa, taken in St Petersburg. He served in Helsinki during the Grand Duchy of Finland and represented Lithuanian (Litvak) Jewish tradition. Finnish Jewish Archives, National Archives of Finland.

Homa worked in Helsinki for the whole decade, until in I89 I he emigrated to the United Kingdom to become the first rabbi of the Lithuanian Orthodox Machzike Hadath community in London. In Helsinki he was sorely missed: 'the Community was most reluctant to let him depart for England, and even after he had left they tried to persuade him to return' (Homa r 953: i 8-r 9). When he visited Helsinki in 1899 , the congregation presented him with a silver goblet and a Hebrew poem praising his qualities. From London, Homa took part in early Zionist activities and attended the First Zionist Congress in Basel in 1898 (ibid. 22.) A few years after Homa's death in I9I2 (Amity 3), the next rabbi chosen to lead Machzike Hadath was the famous Rav Avraham Yitshak Kook.
Schmuel Noson Bukantz (1857-1938), rabbi 1892-1924

The last of the four rabbis during the Grand Duchy of Finland was Schmuel Noson Bukantz. Bukantz was born in 1857 to Leiser Bukanetz and Feige and grew up in Sheta (Šèta) and Kovno. According to Edelmann (2010b, 2009/Io: I92), he received his rabbinical education in various Lithuanian yeshivot. In Kovno, Bukantz studied under Yitshak Elhanan Spektor and Israel Salanter, and in the famous yeshiva of the Musar movement, Slobodka, ${ }^{23}$ he studied under the guidance of Avraham Schenker, one of the students of Israel Salanter, and with Yitshak Blazer, the close friend of Amsterdam (see also Schenker I93 I). Thus Bukantz, like Amsterdam and Werner-Homa, was linked to the Lithuanian Orthodox elite. In I877, Bukantz married Rachel Lea Vershovski (I 854-I923), and they had four children. He received his smikhah in 1884 .

Although there is no information on how Bukantz was recruited as a rabbi in Helsinki, his term lasted for more than thirty years and witnessed essential changes in the status of the Jewish community. The first statutes of the congregation in Helsinki were approved by the governor of the province in 1903, and the synagogue was built in Helsinki in I 905-6. In I 906, several turning points in the community reflected its change from a traditional society into a modern Jewish community. The community reacted with cultural renewal to such new ideologies as Zionism: the members founded a reform heder, ${ }^{24}$ a

23 On the Slobodka Yeshiva, see Stampfer (2OI2: 255-85).

24 These schools were part of a Modern Hebrew school system fostered by the Russian proto-Zionist Hovevei Zion movement. Compared to the traditional hadarim, the curriculum contained also 
sports association Stjärnan (later Makkabi), and a Yiddish-language cultural club. The changes were initiated by the young members of the congregation and challenged the old rabbinical authority. Some of the young Jews also took part in the third conference of Russian Zionists, which convened in Helsinki in I 906, later prompting the founding of Finnish Zionist associations (Muir 2004: 32; Torvinen I989: 79).

The building of the synagogue in the early I goos sparked a debate between those who wanted to follow the style of the Reform congregations in Sweden and in Germany, and those who held on to traditional Judaism. The debate became public in the Russian Jewish journal Hamelitz in early I 90 I, 25 and Bukantz was among the signatories on the side of the traditionalists. Indeed, some members of the congregation had a desire to appear modern in the eyes of Finnish society: when the synagogue was festively opened on 30 August I906, the Reform rabbi Gottlieb Klein from Stockholm was among the invited speakers. There were, in fact, two separate opening ceremonies: the bringing of the Torah scrolls in the morning, where both Bukantz and Klein spoke, and a second ceremony in the afternoon, targeted at the general public, with Finnish Christian guests present, and only Klein held a sermon in Swedish. What is more, the prayers were conducted in Swedish instead of Hebrew, and organ music was played (Muir 2006). Despite the presence of

secular subjects, all taught in Hebrew (Muir 2004: 92-3).

25 See Hamelitz (I6.I.I90I and 23.I.I90I).

Hamelitz (1 860-1903) was the major Hebrew newspaper of Russian Jewry. Ehud Luz (I 988: 7) describes its significance: 'All the various streams, and the bitter wars of words that involved Russian Jewry, found expression in this publication, which played a more important role in Jewish public life than any of its rivals.' such openly 'Reform' elements in the second ceremony, the congregation continued to follow East European Orthodoxy; Edelmann (2orob) interprets this as due to Bukantz's influence.

Edelmann (2010b) shares some pieces of information about Bukantz's term as a rabbi from the archives of the congregation: a year after the Jewish school of Helsinki had been founded in I 893, Bukantz suggested that all Jewish children attend the school, including the children of the families that could not afford tuition. The rabbi's salary also created problems for the economically struggling congregation: extra money had to be collected from the congregants or via loans. ${ }^{26}$ In I9 I 5 , Bukantz established a society for a daily study of the Talmud (Hevra Shas): on the first leaf of the society's pinkas (records), Bukantz is titled as ha-Rav ha-Gaon, 'the Great Rabbi' (Edelmann 20Iob).

After the death of his first wife Rachel, Bukantz married Ester Levit (b. 1890) in I923. He retired in I924, and two years later the couple emigrated to Jerusalem, where some of Bukantz's children were already living. Bukantz passed away in Jerusalem in i 938 (Edelmann 2or ob).

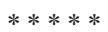

In a draft for his 'Commemorative Chronicle', Weinstein draws some interesting conclusions about the formation of Finnish Jewish Orthodoxy during the time of these four rabbis representing Lithuanian Orthodoxy: 27

26 According to Weinstein (I956), the money for the salaries was collected through karobke (tax on kosher meat), pushke (alms box) and neyder (self-made pledge).

27 Several draft versions exist of Weinstein's 'Commemorative Chronicle', and it appears that he cut and revised some parts quite extensively. 
With Bukanz going on pension in 1924 and him leaving the country two years later, a nearly sixty-year-long period of rabanim of the old generations came to a conclusion, a period during which the congregation became stabilised as an Orthodox Jewish community, with institutions based on the religious-ethical principles: 'Torah, worship and social help'.

A Yiddish version of the same text, found among Weinstein's drafts, in many ways renders the same information in a different tone altogether: Weinstein claims that with Bukantz's leaving 'our golden chain of pious rabbis was broken'. 28 One gets the impression that, according to Weinstein, until then the community had had strong spiritual leaders, but this state of affairs changed radically after Bukantz left. The Jewish community, now in the independent state of Finland, had new and different ideas about what they expected from the rabbinate.

\section{The Academics:}

\section{rabbis after the independence of Finland}

After the independence of Finland in I9I7, the status of the Finnish Jews changed drastically. Besides granting Jews the right to apply for Finnish citizenship, the Law for the Citizens of Mosaic Faith, passed on I 2 January I 91 8, allowed Jews to establish congregations officially (Torvinen I989: I07, 243). On I 9 December the same year, the Helsinki city council accepted the statutes of the Jewish Community of Helsinki and the congregation was added to the register of the religious communities in Finland (Weinstein 1956). According to Weinstein, after the

28 In Weinstein's own Latinisation: 'hot sich bai uns obgebrochn di goldene keit fun rabonim-zadikim'. independence of Finland the community wanted to employ 'an Orthodox, academically trained rabbi'. It was desired that the rabbi should 'correspond to the higher cultural development of the community'. We may ask whether there was also some societal pressure for the Jewish community to employ academically trained rabbis as was the case among the Lutheran ministers in Finland, who routinely held degrees from Finnish universities.

Linguistically and culturally, Jews in Helsinki were acculturating themselves to the Finnish-Swedish middle class and some had achieved high-school and university-level education (Ekholm 2013: 70; Muir 2009: 538). In I9I8, the community founded a modern Hebrew and Swedish-language coeducational school (Kantor et al. 2018: 27), and the years to follow saw the establishment of many new cultural and political associations. Many were supporters of various fractions of Zionism, mostly moderate General Zionism (Torvinen I 989: I 28; Muir 2004: 32, 47-8). Very tight Orthodoxy simply did not fit the lifestyle of Jews in Helsinki any more. Revealing is the notion by the Latvian author Herman Morat (1928), who visited Helsinki at the end of the r92os, that only half of the Jews in Helsinki were frum (Yiddish 'religious'), the rest being halb-frum ('semi-religious').

Apparently the idea of having a modern Orthodox rabbi arose much earlier. Around the mid-r89os the Jewish community sent Abraham Engel (1877-1928), who was considered as an illui, a Talmudic prodigy, to the Slobodka Yeshiva in Kovno, to follow in the footsteps of Werner-Homa and Bukantz (Kantor et al. 2018: 24). However, after a while, the community decided to send him to continue his rabbinical studies in Berlin. Engel enrolled in the Berlin Rabbinical Seminary, directed by Asriel Hildesheimer. 
This seminary, reflecting a positive attitude towards Western culture, had become the centre for training Orthodox rabbis in Europe. The curriculum contained academic study of Judaism, and it was expected that the students should continue their general education at a university level. Hildesheimer believed that they had to directly confront views opposed to tradition and to be convinced that Orthodoxy was in accord with the highest standards of modern scholarship (Shapiro r 999: 76-8). However, Engel abandoned the plan to become a rabbi and continued his studies in a university, eventually earning a doctor's degree in chemistry (Kantor et al. 201 8: 30).

So strong was the desire to begin the new era with a clean slate that when Bukantz retired in I924, the community leaders did not want him to remain in Finland. According to Weinstein's drafts for his 'Commemorative Chronicle', this was done 'so that his remaining would not, God forbid, disturb the work of the new rabbi'. Both Weinstein and Torvinen discuss three Orthodox rabbis with an academic background who served the Jewish community between the world wars and during the immediate post-war years. These rabbis were Scholem Treistman, Simon Federbusch and Elieser Berlinger.

\section{Scholem Treistman (1892-1963), rabbi 1928-9}

Scholem Treistman's nomination launched the period of the 'Orthodox, academically educated rabbis' in Helsinki. Treistman was chosen precisely for having a doctoral degree and a rabbinic education in Germany, the hub of Modern Orthodoxy. The congregation was so thrilled to have Treistman as their new rabbi that they received him with a Torah scroll as his ship docked in Helsinki (Weinstein 1956).
Scholem Treistman was also the first rabbi in Helsinki with a Polish Hasidic background. He was born in Żelechów, in south-eastern Poland, in I 892, to a family of Gur Hasidim. Treistman's father, Eliezer Leib Yehuda (d. I 920), had been the leading rabbi of Łódź, first substituting and after I9I2 replacing the famous rabbi Eliya Hayyim Maizel (Kirshenboim 2007: I 57). Edelmann (2006d) sheds further light on Treistman's biography: in I9I2, he married Chana (b. I 894), the daughter of a wealthy industrial, Mordechai Münzberg, and studied for two years in the yeshiva of Ostrowiec, ${ }^{29}$ supported by his father-in-law. During the First World War, Treistman stayed in Łódź, where his father was employed as the chief rabbi. In his youth, he had become acquainted with the 'Illui of Warsaw', Hayyim Heller, and in 1923-6 he studied in Heller's Bet Midrash ha-Elyon in Berlin together with his brother Simha (b. I 904). This highly exclusive school for rabbinical studies attracted Lithuanian and Polish yeshiva graduates, including the famous Modern Orthodox philosopher J. B. Soloveitchik in the late rg2os. There is no information about where Treistman received his doctoral degree. ${ }^{30}$

After Bukantz's retirement, the congregation had sent Abraham Engel to Berlin to examine three candidates for the rabbinate in 1927 (Edelmann 2006d: 24). The chosen rabbi was Treistman, who came to Helsinki in 1928 with his family. His wife Chana became a member of Hevra Biqqur Holim,

29 There are several towns called Ostrowiec in Poland. Most likely this Ostrowiec was located in the Radom district in eastern Poland.

30 According to Edelmann (2006d: 25), Treistman had studied in universities in Berlin and in Vienna; the newspaper Karjala (23.I I.I 93 I), discussing Treistman's case, adds the University of Würzburg. 
and their children enrolled in the Jewish school (Amity 4). Treistman's appointment in Helsinki lasted one year only: according to Edelmann (2006d), the congregation began to doubt Treistman's smikhah and raised suspicions concerning his doctoral degree. ${ }^{31}$ After an investigation, they claimed that his diplomas were not sufficient for the position. ${ }^{32}$ In I929, Treistman was fired, accused of having misled the congregation with false information (Weinstein I 956).

Despite the unpleasant episode in Helsinki, Treistman began a successful career as a rabbi in Poland, working at least in Warsaw (Fuchs r96r: r 34).33 Already in his youth in Łódź, Treistman had been a religious Zionist activist (Edelmann 2006d), and in the I 930 s he became the co-founder of a society called Yeshurun, politically close to right-wing Revisionist Zionists. When the Second World War broke out he fled to Białystok. In I940, Treistman was arrested by the Soviets and sent to a labour camp in the Arkhangelsk region, where he survived the war. His wife

31 Treistman had presented recommendation letters from several rabbis. In the traditional East European Jewish context, receiving smikhah did not require attendance in a certain school but, rather, gathering relevant amounts of information from classic Jewish sources and being examined by a (prestigious) rabbi who would then give the smikhah. On this process, see Stampfer (2OI 2: 4I).

32 According to Edelmann (2006c), when Treistman was employed in Helsinki, the congregation felt that he was not keeping his end of the contract, for example by not showing up at synagogue service.

33 Information about Treistman's later circumstances comes from the works of Chaim-Leib Fuchs (1 897-1984), a Yiddish journalist and author who after the war wrote about East European Jewish history, especially in Łódź. and two of his four children perished in the Warsaw Ghetto or in Treblinka (Fuchs r 96 I: I 34$) .34$

After repatriation from the Soviet Union, Treistman had a central role in rebuilding religious life in Poland and became a member of the chief rabbinate (Fuchs I96r: I34). He was the first director of the Religious Union of the Mosaic Faith in Poland, founded in I 949 and financed by the American Jewish Joint Distribution Committee (Aleksiun 2003: 840). In 1952, Treistman moved to Israel, publishing articles for the Yiddishlanguage newspaper Letste nayes and writing poetry in Yiddish and in Hebrew. Treistman died in Tel Aviv in r 963 (Fuchs r 972: 36).

\section{Simon Federbusch (1892-1969), rabbi 1931-40}

Simon Federbusch was the next academic rabbi that the congregation in Helsinki recruited. Federbusch was born in Narol, eastern Galicia, in I892. At the time, Narol had its own Hasidic dynasty. Federbusch's father Zwi was a scholar and a lawyer, and his mother Cherna an offspring of a prestigious family of rabbis (Edelmann 2006b). Federbusch received his first smikhah at the age of $\mathrm{I} 7$ from the Hasidic rabbi of Berezhyn, Sholom Mordechai Schwadron (I835-I9I I). In Berezhyn, I 80 kilometres east of Narol, Schwadron headed the local yeshivah, Tushiya. There is no information on where Federbusch resided during the First World War but it is evident there were major changes in his life: in I923, he obtained another smikhah from the Israelitisch-theologische Lehranstalt, a Conservative rabbinical teachers' seminar founded in 1893 in Vienna. He also held a

34 Treistman's grandniece Dor Treistman has submitted pages of testimony to Yad Vashem concerning the fate of the family. 


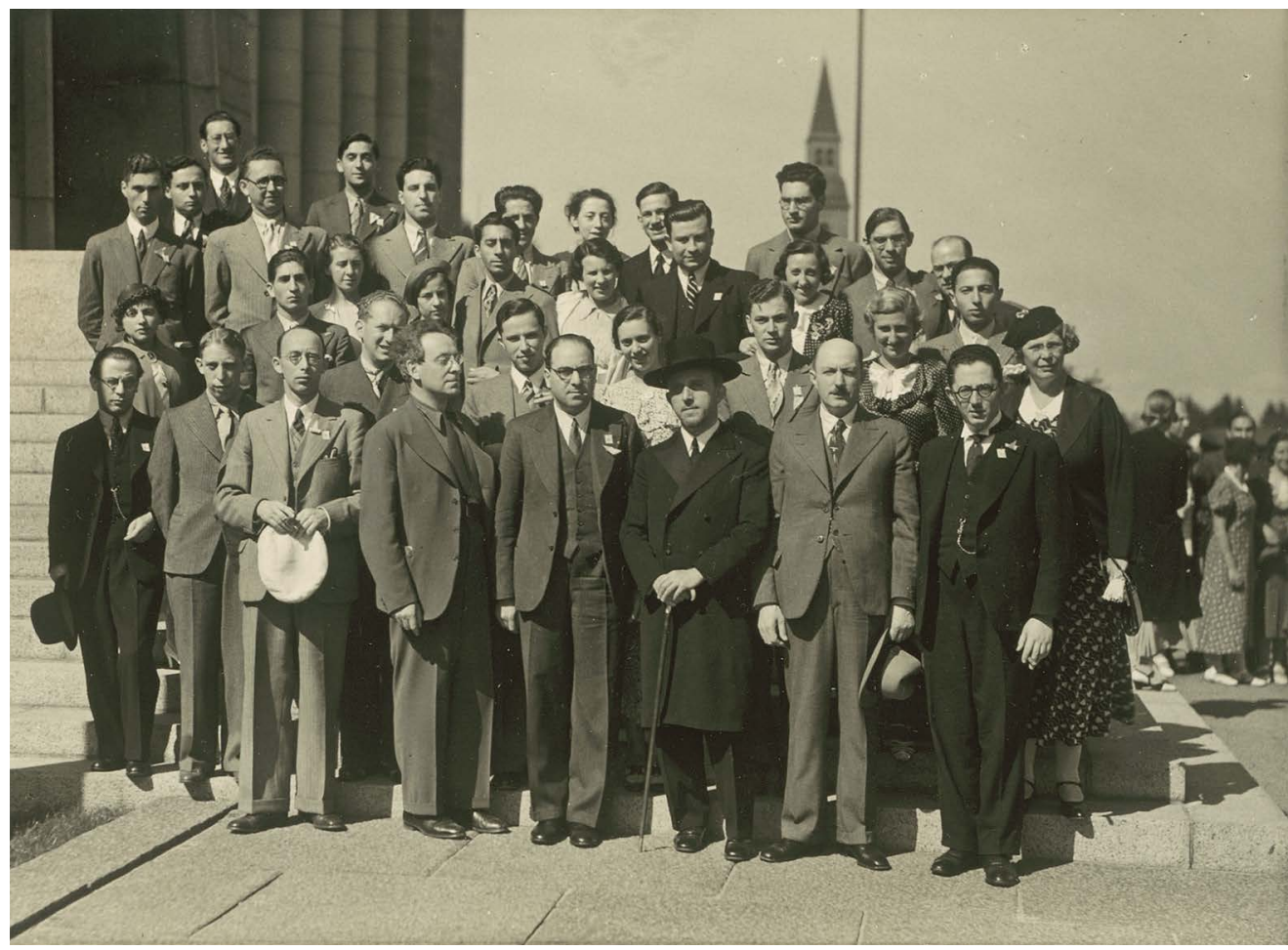

Rabbi Simon Federbusch, on the first row with a black hat and a cane, attending the meeting of the Scandinavian Jewish Youth Association (SJUF) in front of the Finnish Parliament in Helsinki in 1936. Federbusch represented rabbis with academic and Western education during the first decades of Finnish independence. Finnish Jewish Archives, National Archives of Finland.

doctoral degree but there is no information about which university it was from. 35 After his graduation in 1923 , he moved to Lwów (Lviv) and became an editor at several Zionist publications. In I 928 , he married the daughter of a Viennese rabbi, Taube Toni Horowitz (I906-2006) (Edelmann 2006c: 40; Edelmann 2009/I0: 235; Sherman r996: 64).

Federbusch arrived in Finland in I93 I, and in 1933 he was appointed as the first chief rabbi of Finland. ${ }^{36}$ At the same time a new organisation, the Central Council of Jewish Communities in Finland, was established to cover all the Finnish Jewish congregations

35 He had studied in universities in Vienna, Kraków and Lwów (Fuchs I 968: 4I I).

36 This is apparently the first time the title is used.
(Torvinen I989: I I5-I6). Soon Federbusch became a visible figure in Finnish society as well as internationally, making public statements, for example, against the rise of antisemitism. He wrote a work dissecting the famous Russian hoax, The Protocols of the Elders of Zion, and in the Finnish Parliament acted against the plans to outlaw ritual slaughter. In 1935 , he took part in a European conference of chief rabbis in London, which dealt with the Nazi threat, and initiated joint conferences for Nordic rabbis: the first meeting convened in Copenhagen in January I 937 (Edelmann and Muir 20Io).

Since his youth, Federbusch had been active in several religious Zionist organisations and would continue to be a devoted Zionist for the rest of his life. Already as a student in Vienna he founded a Zionist 
youth group, and in 1922 he was elected to the Polish Sejm as a representative of the Jewish national wing. ${ }^{37}$ Two years later he became the head of the religious Zionist organisation Mizrachi of Galicia. In the I930s, Federbusch represented the Finnish Jewish community in the meetings of the Zionist World Congress (Edelmann and Muir 20I0). An avid promoter of Modern Hebrew, Federbusch became a founding member of Ha-qlub ha-ivri ('Hebrew club') as well as increasing the role of religion in the Jewish school in Helsinki (Kantor et al. 201 8: 47). As has been discussed above, during the r93os the Finnish Jewish community was becoming increasingly secularised. Federbusch continued a strongly Orthodox stance and was outspoken against assimilation. In r 937, he submitted a taqqanah (religious ruling) forbidding husbands in mixed marriages to rise to the podium to read the Torah or to take part in the celebration of bne mitsvah (Torvinen I 989: I 27).

At the end of the Winter War (193940), Federbusch emigrated to the United States, and his departure left many of the congregants feeling abandoned. During the Continuation War (194I-4), when Finland was de facto allied with Nazi Germany, Finland's indigenous Jewish population took part in the country's war efforts against the Soviet Union. After the deportation of eight Jewish refugees on 6 November 1942 to Nazi Germany, rumours about the precarious situation of Jews in Finland started to circulate in the American press. On I7 December I943, Federbusch sent a telegram to the Finnish Foreign Ministry urging them to rebut these rumours by publishing an article in the American press (Torvinen I 984: 220).

$37 \mathrm{He}$ was a member of the Sejm between I 922-8 (Hadas 2007: 727-8).
In New York, Federbusch became the head of a Bronx-based yeshivah named after Israel Salanter, the founder of the Musar movement, and took part in the activities of several religious Zionist organisations. Federbusch died in New York in I 969 and was buried in Jerusalem (Edelmann and Muir 2010).

\section{Elieser Berlinger (1904-1985), rabbi 1946-51}

Elieser Berlinger is clearly a case of his own in the series of Finnish rabbis: he was the only one born in Germany. Berlinger was born in Illingen, Saarland, in I904, and graduated from the Berlin Rabbinical Seminary in 1928 , the same school where the Finnish Talmudic prodigy Abraham Engel had studied in the I 890 os. Berlinger worked as a rabbi first in Schönlanke (Trzcianka), Posen (1923-32),38 and in Malmö, Sweden (1932-46). During the war, he took part in the rescue operation of Danish Jews in 1943, and after the war he helped Jewish refugees in Malmö. ${ }^{39}$

From Malmö, Berlinger was invited to Helsinki to be the main speaker when the Finnish president, Carl Gustaf Emil Mannerheim, visited the Helsinki synagogue on 6 December $1944 .{ }^{40}$ In his speech, Berlinger commemorated the fallen Jewish soldiers and expressed gratitude towards Mannerheim (Weinstein I 956). Incidentally, the event mirrored the opening ceremony of the Helsinki synagogue in I 906 with some non-Orthodox elements: both occasions included Finnish esteemed guests, an invited speaker from Sweden and prayers in Swedish.

38 Bart Wallet, personal communication.

39 See 'Eliezer Berlinger is dead', in Jerwish Telegraphic Agency, 6. I I. 1985.

40 At this point, Finland had signed the Moscow Armistice, and the Continuation War had ended. 
After Federbusch's departure the congregation had been left without a rabbi for the duration of the war. Weinstein (1956) notes that during the times when the congregation was left without a rabbi, Mordechai Schwartzman (I875-195 I), who came from Šiuliai, Lithuania, was seen as its spiritual head: he worked as the mohel (circumciser), shohet (slaughterer) and kantor for fortyfive years (I90I-46). Berlinger received an invitation for the rabbinate during his visit in Helsinki, and in r 946, he was appointed as the chief rabbi. With a smikbah from a Modern Orthodox seminary in Berlin, he obviously met the requirements of the congregation. During his time in Helsinki, Berlinger in some cases approved children born to non-Jewish mothers as Jewish after tevilah, immersion in the ritual bath, between the ages of four and seven (Czimbalmos 2018: r69). In I950, Berlinger sent a question to the former head of his alma mater, Berlin Rabbinical Seminary, Yehiel Yacob Weinberg (1884-I966), asking whether it was permitted to continue the tradition of the Qiddush ritual (sanctification blessing recived over wine) in the Helsinki synagogue after the pause caused by the war: Weinberg's answer was affirmative (Edelmann 2009/ I0: 58-9). ${ }^{41}$

After the war, trials against German perpetrators and their collaborators began. In Finland, Berlinger was involved in one of the cases. Maks Szczęśliwy, a survivor of the Shoah living in Finland, had been the head of the Food Supply Department in the Eódź Ghetto and a close associate of Chaim Rumkowski, the infamous Jewish leader of the ghetto. The Central Council of Jewish Communities in Finland decided in 1949 to

41 Berlinger was hesitant because the renewal of the ritual may be understood as a blessing recited unnecessarily. The correspondence is published in Weinberg's classic responsa collection, Seride esh. set up a tribunal with Rabbi Berlinger and two lawyers, referred to in some documents as a bet din (rabbinic court), to investigate Szczęśliwy's actions during the war. The goal was to decide whether Szczęśliwy had committed crimes against humanity. If deemed guilty, his application for membership of the congregation would be declined. The investigation dragged on until 1953 when Szczęśliwy was accepted as a member (Muir 2or 6b: 239-46).

Berlinger decided to leave Finland in I $95^{42}$ and moved to Amsterdam to work as a rabbi. Three years later he was appointed as the chief rabbi of Utrecht, covering most of the Netherlands, excluding Amsterdam, Rotterdam and The Hague. Berlinger was a moderate Orthodox and an activist in the religious Zionist movement Mizrachi, and he strove to value the customs specific to the Dutch Jewish community. ${ }^{43}$ Berlinger died in Utrecht in 1985 .

In the draft versions of his 'Commemorative Chronicle', Weinstein is open and critical towards Treistman, Federbusch and Berlinger. Weinstein writes:

Unfortunately one cannot say that the new era with 'Orthodox, academically trained rabbis' resulted in an elevation of the religious life in the community; quite the opposite. This is because none of them, during the last thirty years since Bukanz left the community, acted as its spiritual leader, or seemed to live up to their calling.

42 Weinstein (I 956) claims that the relations between Berlinger and the congregation had become strained, without, however, supplying any details.

43 Bart Wallet, personal communication; see also van Bekkum and Brasz 2007: 108. 
Weinstein was especially critical of Federbusch, saying that during his time he was more 'Dr Federbusch than Rabbi Federbusch'. It is interesting why Weinstein, who himself was not so religious and had studied in a university, would be so critical towards these academic rabbis and so positive about the old-school Orthodox rabbis. Similar thinking was, however, widespread. According to Shapiro (r 999: 35), 'Nostalgic yearning for the days of old when the authority of the rabbi was thought to have been unquestioned and held sacred by his flock has always been the rabbinic response to communal usurpation of the rabbi's power'. Ultimately, for Weinstein, and possibly for many others of his generation, the three academic rabbis were not 'a beginning for a new golden chain of rabbis' but the decline of the 'golden age' of the rabbinate.

\section{The Shoah survivors:}

\section{rabbis during the Cold War}

During the Second World War, the Finnish Jewish community lost contact with the former Jewish communities in the Baltic countries and Poland, where the members of the community originated from and where the rabbis and religious workers had previously been recruited from. Jewish communities and centres were in ruins, and the surviving remnant was soon cut off from the West by the Iron Curtain. Though among the Western countries, in the post-war volatile political situation Finland fell into the Soviet zone of interest, which affected Finnish foreign policy throughout the Cold War. Torvinen (1989: I78-86) shows how the Finnish Jewish community tried to navigate between the East and the West, in order not to upset the delicate relation Finland had with her eastern neighbour. In practice this meant that the Finnish Jewish communities and the
Central Council of Jewish Communities in Finland, from the early r 95 os on, abstained from joining organisations, accepting invitations to international meetings and signing communiqués that criticised the Soviet Union for its treatment of Jews. This new post-war situation made the recruitment of rabbis and people with expertise in Judaism in general even more challenging. It became obvious that for foreign Jews, Finland, where there were several periods of fear that the Soviets might occupy the country, was not a desirable destination (Muir 2016a: 199).

Between I956 and 1982 three rabbis served in Helsinki: Mika Weiss, Shmuel Beeri and Mordechai Lanxner. Even though these rabbis came to Finland via various countries, there were several things they had in common: they had studied in Europe, they had Hungarian background, and they were Shoah survivors. So far, very little has been discovered about their background: Torvinen mentions them only in passing and Edelmann did not include them in his series of articles in Hakebila. We have gathered information about these rabbis from one autobiography and our contacts abroad, as well as encyclopedias.

\section{Mika Weiss (1913-2001), rabbi 1957-61}

After Berlinger's departure for Utrecht in I95 I, the congregation was left without a rabbi for six years. ${ }^{44}$ The next recruit had been ordained as a rabbi in Budapest in I94I,

44 Difficulties in hiring rabbis were quite common in other European congregations, as well. For example, the congregation of Machzike ha-Dath in London where Homa served as a rabbi had similar problems: when Homa's successor Rav Kook left office I9 I9, the next rabbi was hired only in I 932 (see Machzike ha-Dath community, 'Rav and History'). 
and held a doctorate from the Pázmány Péter Catholic University in Budapest. As a modern, academic rabbi, he met the previous requirements of the congregation for the position well. As a new turn of events, however, Weiss also became the first rabbi with openly liberal leanings, and his smikhah was from a Neolog seminary in Budapest.

Weiss described the main phases of his life in his autobiography (2005).45 Mika (Miksa) Weiss (originally Weiszman) was born in I9I3 in Kiskunfélegyháza, I 35 kilometres south-east of Budapest. Weiss came from a strictly Orthodox home: his father Ferenc Weiszman had studied in Frankfurt under an Orthodox rabbi, and his mother, Teréz Hollander, came from a family of rabbis. Weiss had four siblings; half of the family perished in the Shoah (Weiss 2005: I3-I4).

From a young age Weiss was attracted to liberal versions of Judaism despite his family's Orthodox background. While Weiss's upbringing was strictly Orthodox, he notes that he always yearned to be a 'modern, flexible, conservative ${ }^{46}$ Rabbi' (Weiss 2005: IO-II). For his rabbinical education he enrolled in the National Jewish Theological Seminary, a Neolog rabbinical seminary in Budapest, established in I877. Even before graduating, Weiss accepted a position as an assistant rabbi in the small town of Orosháza. As rabbis were exempted from the harsh labour camps forced by the state on Hungarian Jewish men, he had obtained a false smikhab from a 'diploma mill'. In r 94I, Weiss finally received his rabbinical ordination, and was officially appointed as the

45 The book is based on a Hungarian version Amíg erömból telik published in Debrecen in 1995.

46 Weiss's term 'conservative' refers to Neolog Judaism, a movement formed in Hungary in the mid-nineteenth century, influenced by German Conservative Judaism. chief rabbi of Orosháza in one of its Neolog congregations (ibid. IO-I I , 46-7).

In 1943 , despite being a rabbi, Weiss was taken to forced labour for a period of a month. When Nazi Germany began to exterminate Hungarian Jews in spring I944, Weiss was imprisoned, taken to Austria and marched through various labour camps, including Mauthausen. After the war, he returned to Hungary and became the chief rabbi of the Debrecen Neolog congregation. Almost everyone in his original congregation in Orosháza had been murdered in Auschwitz (Weiss 2005: 81, 103).

The post-war years were hard for the surviving Hungarian Jews, struggling with the immense loss after the Shoah. Weiss describes several antisemitic incidents and seizure of Jewish property in Debrecen by the Communist regime. After the I 956 revolution, Weiss with his wife Marika (née Brüll, b. I924) and a newborn baby began to look for rabbinic positions outside the country. $\mathrm{He}$ received a reply from Kurt Wilhelm (I90065 ), the chief rabbi of the liberal Jewish congregation in Stockholm, and learned about a position in Helsinki. He was invited for an interview in June 1957 and soon received the official offer for the rabbinate. Weiss moved to Finland with his family, and in I959, he was appointed as the chief rabbi of Finland.

In his autobiography, Weiss repeatedly states that he is not Orthodox (for example, Weiss 2005: I 28). Why did he choose to come to Helsinki to work for an Orthodox congregation, and why did the board in Helsinki hire a Neolog rabbi from Hungary and later nominate him as the chief rabbi of Finland? These questions puzzled Weiss himself, who notes (ibid. I 52) that the board made a conscious choice by choosing a non-Orthodox rabbi. During his interview in Helsinki, Weiss succinctly notes the Litvak features of Finnish Orthodoxy: 'They 
practiced their Judaism very strangely' (ibid. I38). For the Jews of Helsinki, Weiss also appeared 'strange'. At the synagogue, one of the congregants jokingly cast doubts on the 'Jewishness' of the future rabbi in Yiddish: 'Rabbi, you don't know what gefilte fish is? You don't speak Yiddish? Tell me, are you really a Jew?' (Weiss 2055: г 36). ${ }^{47}$

Against the backdrop of Finland's own volatile political situation it is intriguing that Weiss chose to come to Finland. On the other hand, his autobiography shows that the family lacked other options. The ambiguity of Weiss's situation is observable between the lines: although he repeatedly commends Finland as a 'free country', he also refers to a constant feeling of 'uncomfortableness' (Weiss 2005: I 37-8, I 5 I). During his r 96 I trip to the United States, his wife sent him a telegram from Stockholm warning him not to return, as the 'Russians have threatened Finland', and claiming that most Jews had already fled the country ${ }^{48}$ (ibid. I 83). Weiss never returned to Helsinki and applied for a green card. The congregation in Helsinki was reluctant to see the family leave, and Weiss (ibid. I 89-9I) later regretted leaving without a proper goodbye and sent a letter explaining his decisions.

In the United States, Weiss was first hired as a rabbi in Flemington, New Jersey, and later in the Conservative Temple B'nai Hayim in Sherman Oaks, California. Settling in the United States, he also worked as a chaplain

47 At the time the congregation was also becoming increasingly secular: an Israeli Hebrew teacher at the Jewish school in Helsinki, Yaakov Frank ( I 956), claims that hardly anyone kept the Shabbat.

48 Marika Weiss probably referred to the so-called Note Crisis in October I96I, a political crisis worsening Soviet-Finnish relations. It is not known whether any Jews left Finland because of the crisis. in hospitals and prisons until his retirement in the r 990 (Weiss 2005: I93ff.).

\section{Shmuel Beeri (1905-?), rabbi 1961-3}

After Mika Weiss's departure, Shmuel (Samuel) Beeri with a smikhah from a Central European Orthodox yeshivah represented a return towards Orthodoxy. Like Weiss, Beeri was a Hungarian Jew; he was, however, the first rabbi to arrive in Helsinki from Israel.

Beeri was born in 1905 in Sziget (Sighetu Marmației) in Máramaros (Maramureş), then part of the Austro-Hungarian Empire, and after I 920, of Romania. Not much information is available about Beeri's background: his father's name was Josef Beeri (Stein), ${ }^{49}$ and he was married twice; with Meriam Weisberg he had one daughter. 50 Beeri received his smikhah from the prestigious Pressburg Yeshivah, ${ }^{51}$ established in 1803 by the rabbi and scholar Moses Sofer (Hatam Sofer). Pressburg (Bratislava) was one of the most influential yeshivot, educating generations of Hungarian Jewish rabbis and cultivating Hungarian Orthodoxy. 52

Before the Second World War, almost 30 per cent of the population in Sziget were Jewish. In I940, Máramaros was annexed back to Hungary with serious implications for local Jews: as many of them had

49 According to a Dutch genealogy site, the father's last name was Stein; see 'Family page' at DutchJewry.org website.

50 See Amity 5 and 'Family page' at DutchJewry.org website. The famous IsraeliAmerican hazzan Joseph Malovany (b. I 94I, Tel Aviv), is the son of Beeri's sister, Freyda (née Stein) (see 'Joseph Malovany').

51 Bart Wallet, personal communication.

52 Traditionally, there were three types of Orthodox yeshivot in Europe: Hasidic, Lithuanian and Hungarian (Stampfer 2OI2: IO). 


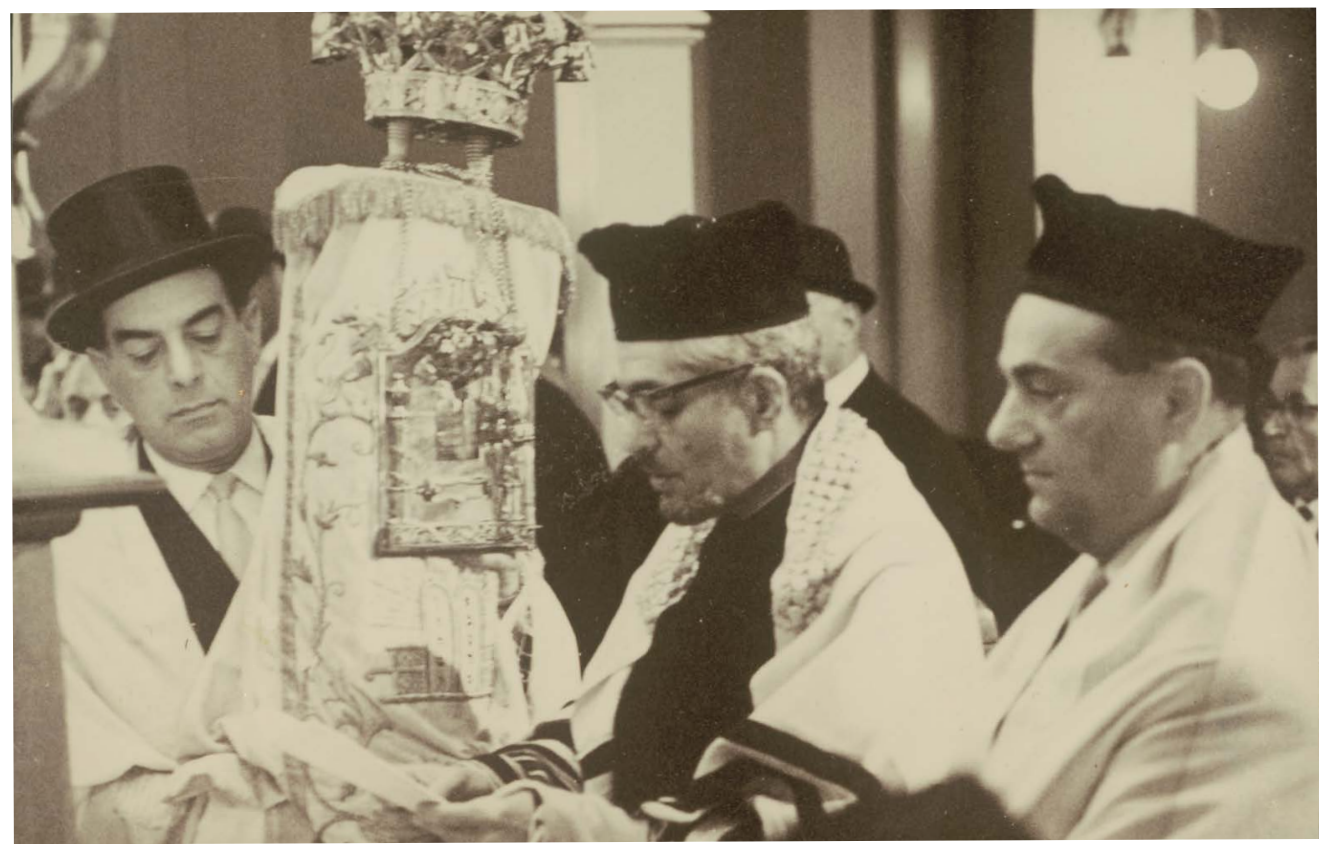

Rabbi Shmuel Beeri in the middle of the picture with Cantor Abraham Schwartzman on the left. Beeri, born in Sziget in the Austro-Hungarian Empire in 1905, was a survivor of the Shoah and arrived in Finland in 1961 after working as a teacher and a rabbi in Israel. Finnish Jewish Archives, National Archives of Finland.

Galician roots, many were deported as 'foreign' to Poland and consequently murdered, and young Jewish men were imprisoned in Hungarian labour camps (Gross and Cohen I983). There is no information how Beeri survived the Nazi mass murders that began in spring I $944 .{ }^{53}$ After the war he emigrated to Israel, where he worked as the head of a yeshiah in Safed and as a high-school teacher in Ramat Gan. ${ }^{54}$

In I953, Beeri travelled to Asmara (now the capital of Eritrea) to found a school for the local Jewish community as part of the initiative of the president, Yizhak Ben-Zvi, to connect Ethiopian Jewry to the State

53 We lack any details about his whereabouts during the Shoah, although, according to some sources, he suffered a great deal during the Shoah and afterwards (see, for example, $H a-T s o f e h, 6.8 .195^{8}$ ).

54 Bart Wallet, personal communication. of Israel. He also co-authored a book on Jewish holidays with the first leader of the Ethiopian Jewish community, Yona Bogale, in Amharic. 55 Beeri stayed in Ethiopia until I 956 (Bard 2002: I I).

In the early i 960 , Beeri was invited from Israel to Helsinki to work as a rabbi. This was the beginning of recruitment of rabbis with an Israeli background and later on, with Israeli rabbinical education (Torvinen I989: I 87). In I 96 I, Beeri was appointed as the chief rabbi of Finland. The most public event during his assignment was his memorial speech after the death of President Ben-Zvi in the synagogue with President Urho Kekkonen present in April I963 (Torvinen 1989). After serving only two years, Beeri, mirroring the path of Berlinger, left Helsinki to be appointed as the

55 Hage yisrael: rosh ha-shanah, yom ha-kippurim, sukkot (Asmara, I 954). 
chief rabbi of The Hague in 1963 . There is no information about the year of his death but he probably returned to Israel after retiring in 1970.56

\section{Mordechai Lanxner (1914-83), deputy rabbi 1968-73, rabbi 1973-82}

Like Weiss and Beeri, Lanxner was a Hungarian survivor of the Shoah who lost many members of his family during the war. Like Beeri, he was from Máramaros and came to Finland via Israel. As opposed to the other two Hungarian rabbis, however, Lanxner was educated in Hasidic yeshivot in Hungary and Romania, and in his obituary he is designated as 'an old-school Hasid' (Hakebila 3/. 983 ).

Mordechai Shimon (Marku Schimon) Lanxner (Veis) was born in I9 44 in Ruszkova (Ruscova), 5 o kilometers south-east of Sziget. Most of the Jewish population in Ruszkova were Vishnitz Hasidim. The town boasted a large yeshivah founded in the late 1920 s by Abraham Shlomo Katz. The yeshivab followed the style of Hungarian yeshivot in its teaching schedule but with strong Hasidic influences. In the memorial book of the Shoah victims of Ruszkova, Lanxner - as the rabbi of Helsinki - is counted among the pupils of the school (Moskovitz I 969/70: IO-I 5, 20-I). Lanxner continued his studies in the Kishinev Hasidic yeshivah, and in 1938 , received his smikhah at the age of 24 (Hakebila 3/I983). ${ }^{7}$

In I940, Máramaros was annexed to Hungary. As mentioned above in Beeri's case, even before the Nazi deportations to Auschwitz began in 1944, Jews in Máramaros were expelled en masse as 'foreigners' 58 to the

56 Bart Wallet, personal communication.

57 Kishinev (Chișinău, the present capital of Moldova) had a Hasidic yeshivab in operation since 1860 (Moskovich 2010).

58 Most of the Jews of the town had migrated
Nazi-occupied Galicia in the north, where thousands of Hungarian Jews were murdered in $\mathrm{r} 94 \mathrm{I}$. There is no information whether Lanxner's family was under a threat of expulsion or whether Lanxner was taken to forced labour. 59

In 1944, many of Lanxner's family members were murdered in Auschwitz. Lanxner supplied the names of the Lanxner-Veis family in the Ruszkova memory book (Moskovitz 1969/70: ro8) and in the Yad Vashem Central Database of Shoah Victims. In I950, Lanxner emigrated to Israel and worked as a licensed shohet (Hakebila 3/ i 983). Lanxner was married to Miriam Hazenfratz (b. I 9 I 4), and they had three children (Amity 6).

After Beeri had left in 1963, the congregation in Helsinki was actively trying to find a more permanent rabbi: both Weiss and Beeri had stayed in Finland for only two years. In 1967, Lanxner moved from Israel to Finland to become the shohet of the community (Hakebila 3/1983). Lanxner did not speak Finnish or Swedish and held his sermons in Yiddish (Muir 2009: 540), and while he was respectfully referred to as kantor rav, in the late r 960 s the congregation continued to search for a rabbi. ${ }^{60}$ Finally in 1973 , Lanxner was nominated for the full position.

During Lanxner's term, synagogue services suffered from a lack of participants, causing difficulties in establishing minyan (ten men required for Jewish public worship). Many congregants called for a more equal status for women during the synagogue

to Ruszkova from western Galicia in the nineteenth century (Moskovitz I 969/70: IO-I I).

59 The same questions could be asked of Beeri, who was born in Sziget and whose circumstances during the Shoah are not known to us.

60 Mercédesz Czimbalmos, personal communication. 
service, and the rising rate of intermarriages caused debates (Torvinen I989: 2I2-I3, 2 I6.) During the 1970 and I980s, more than one hundred persons joined the congregation after converting (Harviainen I989: 164-5). According to Lanxner's obituary in Hakebila (3/1983), he 'showed great flexibility and adaptability towards changed conditions in a way that fortified the continuity of the congregation, without breaking halakhah'; nevertheless, some of his decisions - probably on conversions - were apparently criticised outside Finland. After retiring in I982, Lanxner moved back to Israel, where he died in 1983 (Hakebila 3/r983).

All three rabbis of our last period were Hungarian Shoah survivors. In the I990s, Weiss was interviewed about his experiences during the Shoah and was able to describe them in retrospect in his autobiography. Beeri and Lanxner, however, emerge from our sources as more enigmatic cases. There is not much information available about what happened to these two survivors from Máramaros during the war or in the immediate years following it. Before the r980s, silence surrounding the trauma of the genocide was not uncommon among the survivors, and in the Finnish sources of the late r 950 os up to the early i 980 , the wartime experiences of these three rabbis are never discussed. The silence over the Shoah is palpable, for example, in the fact that in Lanxner's I 983 Finnish obituary in Hakebila his survivor background is not mentioned.

Each of the three rabbis represented a different type of a spiritual leader for the Helsinki congregation. Weiss with his Neolog background seemed to herald a turn towards liberal Judaism, while Beeri had a traditional Hungarian Orthodox education, and Lanxner was an 'old-school' Hasid. Their appointments reflect how difficult it was for the Helsinki congregation to find a common line in its recruitment policy. After the Shoah, old connections in Europe had been severed, and in the case of Beeri and Lanxner, the congregation now turned towards Israel in its search for rabbis.

\section{Conclusions}

We have shown that through its rabbis the small Helsinki Jewish congregation, ostensibly on the periphery of the wider Jewish world, was closely connected to the Jewish centres in Eastern and Western Europe as well as the Middle East. Beginning from its early days, the community became involved in the major internal developments of European Jewry.

All of the ten rabbis recruited to Helsinki between I 862 and I982, except for one, were Orthodox. The first rabbis, who during the Grand Duchy of Finland rooted the Minhag Polin, the traditional Ashkenazi synagogue service, in Helsinki, represented East European and Lithuanian Orthodoxy. After Finnish independence in I9I7, the community sought academically trained rabbis that represented Modern Orthodoxy: this was in congruence with the social and cultural development of the community. Whereas Jac Weinstein, Taimi Torvinen and Moshe Edelmann have offered fairly extensive descriptions of the rabbinate during the Russian rule and the first decades after I9 I7, the third period of the rabbis in our periodisation has so far remained less well known. On the basis of various existing accounts we have demonstrated that after the Second World War the community struggled to keep a consistent line: among the three rabbis, all of whom were Hungarian-born Shoah survivors, one was a liberal Neolog rabbi, one was 
modern Orthodox, and one had traditional Hasidic background.

Almost all the rabbis of Helsinki were active in religious Zionist movements. Among the 'spiritual rabbis', Aba Homa attended several Zionist conferences and was indirectly connected to Rav Kook, the emblematic figurehead for religious Zionism. Later in life, Amsterdam, Schain and Bukantz migrated to Jerusalem. After the 1906 Zionist conference in Helsinki, the Finnish Jewish community was becoming more aware of the various political streams of Zionism. All three 'academic' rabbis were Modern Orthodox and active in religious Zionist parties promoting Jewish nationalism, or were even founding members of Zionist societies both in Finland and abroad. Of our last series of rabbis, Beeri and Lanxner had migrated to Israel after the war, and both returned there after retirement.

Whenever possible, we have paid attention to the families and wives of rabbis. Naftali Amsterdam's wife Rivka, for example, was for a long period the sole person in charge of the family's bakery while her husband worked as a rabbi. This reflects an economical pattern typical for East European Jewish families with yeshivah graduates as son-in-laws. However, often our sources are completely silent about domestic issues: more research is needed on the women's role in a world apparently dominated by men, especially in the Nordic context during the period we have studied.

Despite secularisation, acculturation, mixed marriages and several discussions about changing the denomination of the congregation to become more liberal, the community has upheld Orthodoxy and employed Orthodox rabbis to this day. ${ }^{61} \mathrm{~A}$ possible

61 The Jewish Community of Helsinki has continued to employ Orthodox rabbis, most of who have studied in Israeli yeshi- contributory factor here may be that for small communities Orthodoxy functions as a common denominator, while a Reform congregation would exclude Orthodox Jews. ${ }^{62}$ As we have shown, the first debates about the denomination took place as long ago as I90I, when a group of congregants wanted to adopt Reform Judaism, as was the case, for instance, in the capital of the neighbouring Sweden that the Helsinki community held in high regard. Similar debates about changing the denomination have appeared on the pages of the community's journal Hakehila at the beginning of the twenty-first century, as congregants have discussed the discrepancy between the official Orthodoxy of the congregation and the daily religiosity, lifestyle and views of its members.

As we have demonstrated, the rabbis and their backgrounds in many ways reflect the community and the changes that have taken place among the Jews of Helsinki. However, more research is needed to understand how the rabbis influenced the religious customs and the 'lived religion' of the congregants. The Jewish Community of Helsinki is unique with its Cantonist history and roots in East European Litvak traditions. Perhaps it is this legacy and identity that has upheld, despite everything, a continuous string - a 'golden chain'- of Orthodox rabbis.

vot. Since 1982 Ove Schwartz (I $982-7$ ), Lazar Kleinman (-I 992), Michael Aloni (I995-6), Moshe Edelmann (I 999-20 I 2) and Simon Livson (201 2-) have served in Helsinki. Besides the rabbi of the Jewish Community of Helsinki there is currently also a Hasidic rabbi, Rabbi Benjamin Wolff (2003-) of Lubavitch Finland.

62 We can see a similar situation in the Oslo Jewish Community, where the synagogue is Orthodox while most of the members are not (Stene 2012: I49). 
Rabbis in Helsinki 1867-1982

\begin{tabular}{|c|c|c|c|c|c|c|}
\hline Name & $\begin{array}{l}\text { Rabbi in } \\
\text { Helsinki }\end{array}$ & Born in & $\begin{array}{l}\text { Rabbinical } \\
\text { education* }\end{array}$ & $\begin{array}{l}\text { Denomin- } \\
\text { ation** }\end{array}$ & $\begin{array}{l}\text { Academic } \\
\text { studies }\end{array}$ & $\begin{array}{l}\text { Destin- } \\
\text { ation after } \\
\text { Finland }\end{array}$ \\
\hline Naftali Amsterdam & $1867-75$ & $\begin{array}{l}\text { 1832, Salantai, } \\
\text { Lithuania, } \\
\text { Russian Empire }\end{array}$ & $\begin{array}{l}\text { Rabbinical stud- } \\
\text { ies in Vilna and } \\
\text { Kovno }\end{array}$ & $\begin{array}{l}\text { Lithuanian } \\
\text { Orthodox }\end{array}$ & No & $\begin{array}{l}\text { Lithuania, } \\
\text { Palestine }\end{array}$ \\
\hline Avrohom Schain & $1876-81$ & $\begin{array}{l}\text { 1841/2, Novo } \\
\text { Aleksandrovsk } \\
\text { (Zarasai), Lithu- } \\
\text { ania, Russian } \\
\text { Empire }\end{array}$ & Not known & $\begin{array}{l}\text { Lithuanian } \\
\text { Orthodox }\end{array}$ & No & $\begin{array}{l}\text { Scotland, } \\
\text { Palestine }\end{array}$ \\
\hline $\begin{array}{l}\text { Abraham Werner- } \\
\text { Homa }\end{array}$ & $1881-91$ & $\begin{array}{l}\text { 1836, Telšiai, } \\
\text { Lithuania, Russian } \\
\text { Empire }\end{array}$ & $\begin{array}{l}\text { Rabbinical stud- } \\
\text { ies in Žagarè } \\
\text { and Telšiai, } \\
\text { Lithuania }\end{array}$ & $\begin{array}{l}\text { Lithuanian } \\
\text { Orthodox }\end{array}$ & No & UK \\
\hline $\begin{array}{l}\text { Shmuel Noson } \\
\text { Bukantz }\end{array}$ & $\begin{array}{l}1892- \\
1924\end{array}$ & $\begin{array}{l}\text { 1857, Šèta, } \\
\text { Lithuania, Russian } \\
\text { Empire }\end{array}$ & $\begin{array}{l}\text { Slobodka } \\
\text { Yeshivah, Kovno }\end{array}$ & $\begin{array}{l}\text { Lithuanian } \\
\text { Orthodox }\end{array}$ & No & Palestine \\
\hline Scholem Treistman & $1928-9$ & $\begin{array}{l}\text { 1892, Żelechów, } \\
\text { Poland, Russian } \\
\text { Empire }\end{array}$ & $\begin{array}{l}\text { Ostrowiec } \\
\text { Yeshivah / Bet } \\
\text { Midrash } \\
\text { ha-Elyon, Berlin }\end{array}$ & $\begin{array}{l}\text { Hasidic / } \\
\text { Modern } \\
\text { Orthodox }\end{array}$ & $\begin{array}{l}\text { In Berlin and } \\
\text { in Vienna } \\
\text { (apparently } \\
\text { without a } \\
\text { degree) }\end{array}$ & $\begin{array}{l}\text { Poland, } \\
\text { Israel }\end{array}$ \\
\hline Simon Federbusch & $1931-40$ & $\begin{array}{l}\text { 1892, Narol, } \\
\text { Galicia, Austria- } \\
\text { Hungary }\end{array}$ & $\begin{array}{l}\text { Berezhyn } \\
\text { Yeshivah / } \\
\text { Israelitisch- } \\
\text { theologische } \\
\text { Lehranstalt, } \\
\text { Vienna }\end{array}$ & $\begin{array}{l}\text { Hasidic / } \\
\text { Conserva- } \\
\text { tive }\end{array}$ & $\begin{array}{l}\text { PhD but no } \\
\text { information } \\
\text { where from }\end{array}$ & USA \\
\hline Elieser Berlinger & $1946-51$ & $\begin{array}{l}\text { 1904, Illingen, } \\
\text { Germany }\end{array}$ & $\begin{array}{l}\text { Berlin Rabbini- } \\
\text { cal Seminary }\end{array}$ & $\begin{array}{l}\text { Modern } \\
\text { Orthodox }\end{array}$ & Not known & $\begin{array}{l}\text { The Nether- } \\
\text { lands }\end{array}$ \\
\hline Mika Weiss & $1957-61$ & $\begin{array}{l}\text { 1913, Kiskunféle- } \\
\text { gyháza, Austria- } \\
\text { Hungary }\end{array}$ & $\begin{array}{l}\text { National Jewish } \\
\text { Theological } \\
\text { Seminary, } \\
\text { Budapest }\end{array}$ & $\begin{array}{l}\text { Neolog } \\
\text { (Hungari- } \\
\text { an liberal } \\
\text { and mod- } \\
\text { ernist) }\end{array}$ & $\begin{array}{l}\text { PhD from } \\
\text { Pázmány } \\
\text { Péter Cath- } \\
\text { olic Universi- } \\
\text { ty, Budapest }\end{array}$ & USA \\
\hline Shmuel Beeri & $1961-3$ & $\begin{array}{l}\text { 1905, Sziget, } \\
\text { Austria-Hungary }\end{array}$ & $\begin{array}{l}\text { Pressburg } \\
\text { Yeshivah, } \\
\text { Bratislava }\end{array}$ & $\begin{array}{l}\text { Hungarian } \\
\text { Orthodox }\end{array}$ & Not known & $\begin{array}{l}\text { The Nether- } \\
\text { lands, Israel }\end{array}$ \\
\hline $\begin{array}{l}\text { Mordechai Lanx- } \\
\text { ner }\end{array}$ & $1968-82$ & $\begin{array}{l}\text { 1914, Ruszkova, } \\
\text { Austria-Hungary }\end{array}$ & $\begin{array}{l}\text { Ruszkova Yeshi- } \\
\text { vah / Kishinev } \\
\text { Yeshivah }\end{array}$ & Hasidic & No & Israel \\
\hline
\end{tabular}

* In the case of the earliest, 'spiritual' rabbis we often lack information about where they had attended a yeshivah.

** By 'denomination' we refer to the rabbinic education the rabbis had received in yeshivot or at rabbinical seminaries. 
Dr Simo Muir is currently an honorary research associate at the Department of Hebrew and Jewish Studies, University College London, and he is part of the 'Boundaries of Jewish Identities' project at Åbo Akademi University. He received his PhD in Yiddish linguistics at the University

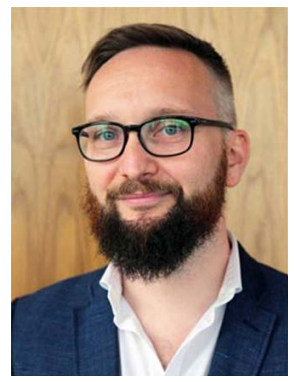
of Helsinki in 2004, and has published widely on Jewish history in Finland. He is a contributing co-editor of Finland's Holocaust: Silences of History (Palgrave Macmillan, 2013). His latest articles include 'The plan to rescue Finnish Jews in 1944' (Holocaust and Genocide Studies, 30(1), 2016) and "'Mother Rachel and her children": artistic expressions in Yiddish and early commemoration of the Holocaust in Finland' (East European Jewish Studies, 48(3), 2018).

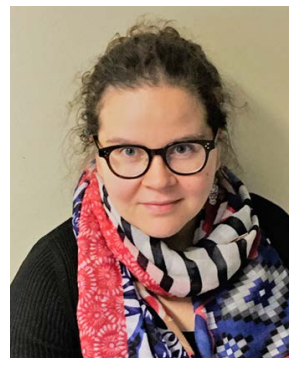

Dr Riikka Tuori is a university lecturer in Middle Eastern studies at the University of Helsinki, where she teaches Hebrew and Jewish studies. She has also worked as a research associate at the Seminar für Judaistik, Goethe-Universität Frankfurt am Main. Her current research interests include early modern Judaism and Hebrew literature, Jewish mysticism and poetry. She has co-edited the first Finnishlanguage Talmudic anthology (Gaudeamus 2018). Her latest article is 'Renewal and tradition in devout Hebrew poetry: the case of the early modern Karaites in Poland-Lithuania' (Zutot, 16(1), 2019).

\section{Sources and literature}

Alderman, Geoffrey, I 992. Modern British Jewry (Oxford, Clarendon Press)

Aleksiun, Natalia, 2003. 'Związek Religijny Wyznania Mojżeszowego w Polsce' Polski stownik judaistyczny, I, ed. Zofia Borzymińska and Rafał Żebrowski (Warsaw, Prószyński i S-ka), pp. 840-I

Amity r. 'Jakob Jakobowitsch', Meliza's

Genealogy, genealogical database, <https:// www.amitys.com/webtrees/individual. php?pid=I 7 I 78 \&ged $=$ Gedcom.ged $>$ (accessed 31.3.2019)

Amity 2. 'Abraham Schain', Meliza's
Genealogy, genealogical database, <https:// www.amitys.com/webtrees/individual. php?pid=I9893\&ged $=$ Gedcom.ged $>$ (accessed 3.3.2019)

Amity 3. 'Rabbi Abraham Aba Werner', Meliza's Genealogy, genealogical database, <https:// www.amitys.com/webtrees/individual. php?pid=I I 60 \&ged $=$ Gedcom.ged $>$ (accessed 3I.3.2019)

Amity 4. 'Rabbi Scholem Treistman', Meliza's Genealogy, genealogical database, <https:// www.amitys.com/webtrees/individual. php?pid=I9894\&ged $=$ Gedcom.ged $>$ (accessed 31.3.2019)

Amity 5. 'Rabbi Shmuel Beeri', Meliza's Genealogy, genealogical database, <https:// www.amitys.com/webtrees/individual. php?pid $=I_{98} 97 \&$ ged $=$ Gedcom.ged $>($ accessed 31.3.2019)

Amity 6. 'Rabbi Mordechai Lanxner', Meliza's Genealogy, genealogical database, <https:// www.amitys.com/webtrees/individual. php?pid $=$ I $9898 \&$ ged $=$ Gedcom.ged $>($ accessed 3I.3.2019)

Bard, Mitchell G., 2002. From Tragedy to Triumph: The Politics behind the Rescue of Ethiopian Jewry (Westport, Praeger)

Bekkum, Wout van, and Chaya Brasz, 2007. 'Netherlands, The (Holland): postwar and contemporary period', Encyclopaedia Judaica, I 5 , ed. Michael Berenbaum and Fred Skolnik (Detroit, MacMillan Reference), pp. Io6-9

Collins, Kenneth, I 990. Second City Jerwry: The Jews of Glasgow in the Age of Expansion 17901919 (Glasgow, Scottish Jewish Archives)

Czimbalmos, Mercédesz, 20 I 8. 'From Yidishe khasene to civil marriage: the history of intermarriages in the Jewish Community of Helsinki', Jewish Studies in the Nordic Countries Today, ed. Ruth Illman and Björn Dahla, Scripta Instituti Donneriani Aboensis, 27 (Turku/Åbo, Donner Institute), pp. I 5974, <https://doi.org/I0.30674/scripta.7007 I > Edelmann, Moshe, 200I. The Traditional Order of Synagogue Service in the Jewish Community of Helsinki, trans. Taija Chaija Votkin (Helsinki, unpublished)

2006a. 'Synagogan Ioo ensimmäistä vuotta: kertomus kolmesta Helsingin seurakunnan rabbista', Hakebila, I, pp. 24-6 2006b. 'Rabbi Shmuel Noson Halevi Bukantz', Hakehila, 2, pp. 26-8 2006c. 'Rabbi Simon Federbusch', Hakebila, 3-4, pp. 39-4I 
2006d. 'Tohtori vastaan "rabbi”. Tapaus

Treistman 1927-1932', Hakebila, 5, pp. 24-6

-2009/ı. Tsfunot ha-tsafon: she'elot $u$-tshuvot ve-divre torah she-megoram mearatsot ha-sqandinaviot, artsot ha-tsafon. Heleq alef (Jerusalem)

20 10a. 'Amsterdam, Naftali (I $832-$ I 916)', Kansallisbiografia-verkkojulkaisu, Studia Bibliographica, 4 (Helsinki, SKS, I 997-), <https://kansallisbiografia.fi/ kansallisbiografia/henkilo/9790> (accessed 31.3.2019)

2orob. 'Bukantz, Schmuel (1857I 938)', Kansallisbiografia-verkkojulkaisu, Studia Bibliographica, 4 (Helsinki, SKS, I 997-), <https://kansallisbiografia.fi/ kansallisbiografia/henkilo/9305> (accessed 31.3.2019)

Edelmann, Moshe, and Simo Muir, 2oro.

'Federbusch, Simon (1 892-1 969)', Kansallisbiografia-verkkojulkaisu, Studia Bibliographica, 4 (Helsinki, SKS, I 997-), <https://kansallisbiografia.fi/ kansallisbiografia/henkilo/9320> (accessed 31.3.2019)

Ekholm, Laura, 201 3. 'Boundaries of an Urban Minority: The Helsinki Jewish Community from the End of Imperial Russia until the I 970s', $\mathrm{PhD}$ dissertation, University of Helsinki

Etkes, Immanuel, I989. 'Marriage and Torah study among the Lomdim in Lithuania in the nineteenth century', The Jerwish Family: Metaphor and Memory, ed. David Kraemer (Oxford University Press), pp. I 53-78

I 993 . Rabbi Israel Salanter and the Mussar Movement. Seeking the Torah of Truth (Philadelphia, JPS)

'Family page', DutchJewry.org, <https://www. dutchjewry.org/genealogy/duparc/I 7 I 73 . shtml> (accessed 3 I.3.2019)

Frank, Yaakov, I 956. 'Ziqqatam shel yehude Finland le-yisrael', Ha-Tsofeh, I 4. I 2.I 956

Fuchs, Chaim-Leib, I 96 I. 'Treystman, Sholem', Leksikon fun der nayer yidisher literature, 4 (New York, Alveltlekher yidisher kulturkongres), p. I34

- 968 . 'Federbush, Shimen', Leksikon fun der nayer yidisher literature, 7 (New York, Alveltlekher yidisher kultur-kongres), pp. 4IO-I I

-1972. Lodzsh shel mayle: dos yidishe gaystike un derhoybene Lodzsh (Tel Aviv, Peretz)

Gross, S. Y., and Y. Yosef Cohen (eds.), I 983.
The Marmaros Book: In Memory of 160 Jewish Communities (Tel Aviv, Beit Marmaros), $<$ https://www.jewishgen.org/yizkor/ maramures/maramures.html> (accessed 31.3.2019)

Hadas, Gershon, 2007. 'Simon Federbusch', Encyclopaedia Judaica, 7, ed. Michael Berenbaum and Fred Skolnik (Detroit, MacMillan Reference), pp. 727-8

Hakehila 3/. 983 .'Harav M. S. Lanxner in Memoriam', Hakebila, 3

Halén, Harry, 2004. 'Historian lehtiä. Rabbin asema Suomessa i 858-i 868', Hakehila, 2, pp. $27-9$

Harviainen, Tapani, r989. 'Suomi', Juutalaisten bistoria, ed. Karl-Johan Illman and Tapani Harviainen (Helsinki, Gaudeamus), pp. I $53-65$

I 998. 'Juutalaiset Suomessa', Juntalainen kulttuuri, ed. Tapani Harviainen and KarlJohan Illman (Helsinki, Otava), pp. 291-304

Homa, Bernhard, 1953. A Fortress in Anglo-Jewry: The Story of Machzike Hadath (London, Vallentine)

Jacobsson, Santeri, I 95 I. Taistelu ibmisoikeuksista. Yhteiskunnallis-bistoriallinen tutkimus Ruotsin ja Suomen juutalaiskysymyksen vaiheista (Jyväskylä, Gummerus)

'Joseph Malovany' [in Hebrew], Wikipedia, <https://he.wikipedia.org/wiki/\%D7\% $\% 9 \%$ D 7\%95\%D7\% ${ }_{7} \% \mathrm{D}_{7} \% \mathrm{~A}_{3}{ }_{2} \mathrm{D}_{7} \% 9{ }_{9} \mathrm{E} \% \mathrm{D}_{7} \%$ ${ }_{9} \mathrm{C} \% \mathrm{D}_{7} \% 95 \% \mathrm{D}_{7} \%{ }_{9}$ г $\% \mathrm{D}_{7} \% \mathrm{~A}_{0} \% \mathrm{D}_{7} \% 99>$ (accessed 31.3.2019)

Kantor, Dan, Laura Ekholm, Simo Muir, Riitta Nurmi, and Daniel Weintraub (eds.), 2018. Kyläkoulu keskellä kaupunkia. Helsingin Juutalainen Ybteiskoulu 100 vuotta (Helsinki, Helsingin Juutalainen Yhteiskoulu)

Kaplan Appel, Tamar, 2010. 'Crown Rabbi', YIVO Encyclopedia of Jews in Eastern Europe, $<$ http://www.yivoencyclopedia.org/article. aspx/Crown_Rabbi> (accessed 3 I.3.20 I 9)

Kirshenboim, Shimson Leib, 2007. 'Lodz, social life and culture', Encyclopaedia Judaica, I3, ed. Michael Berenbaum and Fred Skolnik (Detroit, MacMillan Reference), pp. I 56-8

Lipetz, Dov, Natan Goren, et al., I 967. 'Naftali Amsterdam', Yahadut Lita, 3, ed. Refa'el Hasman (Tel Aviv, Am ha-sefer), p. 29

Lowenstein, Steven, I 997. 'The shifting boundary between eastern and western Jewry', Jewish Social Studies, New Series, 4(I), pp. 60-78, <https://doi.org/10.2979/jss.1997.4.I.6o>

Luz, Ehud, 1988. Parallels Meet: Religion and 
Nationalism in the Early Zionist Movement (1882-1904) (Philadelphia, New York, Jerusalem,JPS)

Machzike ha-Dath community, 'Rav and History', <http://machzikehadath.com/ history/> (accessed 3I.3.2019)

Meyer, Michael A., 20 оo. 'Reform, religious', YIVO Encyclopedia of Jerws in Eastern Europe, $<$ http://www.yivoencyclopedia.org/article. aspx/Reform_Religious> (accessed 31.3.20I9)

Mirsky, Yehudah, 2o Io. 'Musar movement', YIVO Encyclopedia of Jews in Eastern Europe, <http://www.yivoencyclopedia.org/ article.aspx/Musar_Movement> (accessed 31.3.2019)

Morat, Tsvi (Herman), 1928. Idn in di baltishe melukhes: interesante bilder fun lebn (Riga)

Moskovich, Wolf, 20 Iо. 'Kishinev', YIVO Encyclopedia of Jerws in Eastern Europe, $<$ http://www.yivoencyclopedia.org/article. aspx/Kishinev> (accessed 31.3.2019)

Moskovitz, Y.Z. (ed.), I969/7o. Sefer le-zikkaron qdoshe Rosqova ve-Zublas mehoz Marmaros she-nispu 'al yede ha-tsrorer ha-natsi ve-'ozrav ha-bungariyim bishnot ha-shoah (Tel Aviv)

Muir, Simo, 2004. Yiddish in Helsinki: Study of a Colonial Yiddish Dialect and Culture, $\mathrm{PhD}$ dissertation, University of Helsinki

2006. 'Der khanukes-habais fun der ershter jidisher shul in Finland. Suomen ensimmäisen synagogan vihkiäiset', Hakebila, 3-4, pp. 36-8

2009. 'Jiddišistä ruotsin kautta suomeen. Helsingin juutalaisten kielenvaihdoista ja etnolektistä', Virittäjä, I I 3 (4), pp. 533-56 _o го. 'Jac Weinstein (1883-I 976)', Kansallisbiografia-verkkojulkaisu, Studia Bibliographica, 4 (Helsinki, SKS, I $\left.997^{-}\right),<$https://kansallisbiografia.fi/ kansallisbiografia/henkilo/9302 > (accessed 3. .3 .2019 )

20I6a. "Not on the Jewish migration route": Finland and Polish Holocaust survivors, I 945-1 948', Yad Vashem Studies, 44(I), pp. I $77^{-205}$

20I6b. Ei enää kirjeitä Puolasta. Erään juntalaissuvun kohtalonvuodet (Helsinki, Tammi)

Petrovsky-Shtern, Yohanan, 2008. Jews in the Russian Army, 1827-1917: Drafted into Modernity (Cambridge University Press)

'Rabbi Shyne: Scottish Jewish Archives Centre', The Glasgow Story, <https:// www.theglasgowstory.com/ image/?inum $=$ TGSEoo74 $\mathrm{I}>$ (accessed 3I.3.2019)

Schenker, Shmuel, r93r. 'Lema'an ha-'emet lo ehshe', Do'ar ha-yom, 23.IO.I 93 I

Shapiro, Marc B., I 999. Between the Yeshiva World and Modern Orthodoxy: The Life and Works by Rabbi Jebiel Jacob Weinberg 1884-1966 (London, The Littman Library of Jewish Civilization)

Sherman, Moshe, D. 1996. Orthodox Judaism in America: A Biographical Dictionary and Sourcebook (Westport, Greenwood Press)

Stampfer, Shaul, 2O I 2. Lithuanian Yeshivas of the Nineteenth Century (Oxford, The Littman Library of Jewish Civilization)

Stene, Nora, 20I 2. 'Autoritet og autoritetens grenser. Den ortodokse rabbineren som religiøs leder i Det Mosaiske Trossamfund', Religiøse ledere. Makt og avmakt i norske trossamfunn, ed. Cora Alexa Døving and Berit S. Thorbjørnsrud (Oslo, Universitetsforlaget), pp. I $46-68$

Torvinen, Taimi, I 984. Pakolaiset Suomessa Hitlerin valtakaudella (Helsinki, Otava) - i 989 . Kadimah. Suomen juutalaisten bistoria (Helsinki, Otava)

Weinstein, Jac, I 956. Minneskrift till 50-årsdagen av Judiska Församlingen $i$ Helsingfors synagogas invigning den 30 augusti 1956, unpublished manuscript, National Archives of Finland, Finnish Jewish Archives, box 439

- 963. 'Judisk gudstjänst i Ateneum', Makkabi. Organ for judisk kultur och idrottsliv i Finland, October, pp. 3, I 2

I 964. 'Chevra Bikur Cholim 85 år', Makkabi. Organ for judisk kultur och idrottsliv i Finland, 2, pp. 6-7, I 2-1 3

Weiss, Mika, and Burton A. Kittay 2005. As Long as I Have the Strength: The Autobiography of Rabbi Mika Weiss (Portland, Our Town Publishing)

Wengeroff, Pauline 1 908. Memoiren einer Grossmutter. Bilder aus der Kulturgeschichte der Juden Russlands im 19 Jahrbundert, vol. I (Berlin)

Wodziński, Marcin 201 8. Hasidism: Key Questions (Oxford University Press)

Zalkin, Mordechai 20I 7. Rabbi and Community in the Pale (Jerusalem, Magnes Press) 